\title{
Communications Equipment: What Has Happened to Prices?
}

June 2003

Mark Doms

Federal Reserve Bank of San Francisco

Mark.doms@sf.frb.org

The author thanks Neal Dunnay of KMI and Brian Van Steen of RHK for providing data and technical guidance and suggestions. Andrew Batchelor, Niels Burmester, Jon Eller, Susan Polatz, Brigitte van Beuzekom, Courtney Coker, and Margaret Macleod provided research assistance. The author also thanks Carol Corrado, Dan Sichel, Matt Shapiro, for input and advice, and Christopher Greene for editorial comments. 


\section{Introduction}

Measuring prices for classes of goods that exhibit rapid rates of technological change raises special challenges. Over the past several decades, new techniques and data sources have been developed to in response to these challenges. In fact, an extraordinary amount of attention has been placed on accurately measuring computer prices and the results of these efforts have been incorporated into the National Income and Product Accounts (NIPAs). ${ }^{1}$ Attention was focused on computers because price declines for computers were easily observed and computers were a growing share of total investment.

One area where there has been rapid technological change but relatively little effort in terms of measuring prices is communications equipment. This is surprising since breakthroughs in communications technology have been a necessary ingredient in constructing the "new economy", as witnessed by the widespread use and growth of the Internet, the creation of office networks, the ability to transmit huge amounts of information over a global fiber optic network, the increased use of cell phones, the increased capacity of cable television networks, and so on.

Despite the breathtaking advances in communications equipment, the official price indexes for communications equipment from the Bureau of Labor Statistics (BLS) have barely changed over the past decade. According to the BLS, producer prices for communications equipment increased an average of 0.2 percent between 1991 and 2000. ${ }^{2}$ The prices for communications equipment stand in stark contrast to those for computers where BLS shows prices falling an average of 14.5 percent over this period. The Bureau of Economic Analysis (BEA) measure for computers shows prices falling 17.6 percent. ${ }^{3}$

Prices of communications equipment, by contrast, have received scant attention. There are several reasons why research has not progressed more quickly in the field of communication equipment prices relative to computer prices. First, communications equipment covers a more diverse set of products than computers. Communications equipment covers such diverse--and arcane--items as cell phones, alarm systems, fiber optic gear, and local area network (LAN) equipment. Second, obtaining data on communication equipment prices is more difficult than it is for computers. Large chunks of communications equipment are sold to relatively few

\footnotetext{
${ }^{1}$ For a summary, see Triplett (2001).

${ }^{2}$ The producer price index (PPI) for industry 366 increased at an annual rate of 1.1 percent between 1990 and 1997. Between 1997 and 2000, the PPI fell at an annual rate of 1.2 percent.

${ }^{3}$ The BEA measure for computers used to rely on its own measure of prices for larger computers, and the BEA price series fell faster than the comparable BLS series. Consequently, the BEA computer deflator falls faster than BLS's.
} 
customers (for instance, telecom service providers), and prices are not regularly published in periodicals such as Computer Shopper.

Table 1 shows some measures of both computer and communications equipment investment in the 1990s. Line 3 shows that the growth rates in nominal investment for computers and communications equipment were remarkably similar during the 1990s. Additionally, there is also an eerie resemblance in the level of investment spending in computer and communications equipment. These facts make it all the more surprising that more research has not been conducted on the prices of communications equipment.

As mentioned before, the biggest difference between the official investment statistics on communications equipment and computers is what has happened to official prices. As shown on line 7 of table 1, BEA's official prices for computers fell 17.6 percent on average during the 1990s, whereas communications equipment prices fell an average of 2.1 percent. One reason why the BEA's official prices for communications equipment falls faster than the BLS PPI is that the BEA has incorporated alternative price measures for two communications equipment components. The first is for central office switching equipment, where Grimm (1997) found that prices fell an average of 9.1 percent per year. The second is for local area network (LAN) equipment, where Chris Forman and I found that prices fell an average of 17.5 percent per year between 1995 and $2000 .^{4}$

Why do I care about communications equipment prices, or, why do I think a priori that communications equipment prices fell faster than the BLS data would lead us to believe? First, the small handful of studies that have examined portions of communications equipment have found that prices have fallen quickly, but perhaps not as much as computers. With that said, these studies did not look at a random sample of the communications equipment universe, and they also have not examined the areas where technological change has been most rapid. Second, as stated earlier in the introduction, there are numerous instances of technological change in several parts of the communications equipment spectrum that have revolutionized communication services. Third, as just discussed, big bucks have been spent on communications equipment, so deriving more accurate measures of prices would likely have consequences for top-line measures of economic activity. For instance, Jorgenson and Stiroh (2000) go so far as to run simulations under different scenarios for communications equipment prices.

\footnotetext{
${ }^{4}$ See Doms and Forman (2003).
} 
To illustrate the potential importance of deriving more accurate measures of communications equipment, table 2 shows the contributions of computers and communication equipment to gross domestic product (GDP) and equipment and software (E\&S) growth during the 1990s. ${ }^{5}$ Line 2 shows that computer investment contributed an average of almost 0.3 percentage point to the average annual growth rate of GDP during the last decade, with a larger contribution in the second half of the 1990s. In contrast, communications equipment investment contributed only about a third as much as computers did. A similar pattern holds for E\&S spending.

Given the similar nominal shares and growth rates of computers and communications equipment, it seems that the potential payoff of "fixing" communications equipment prices relative to the cost of doing so may be high. The question then arises of how can we accurately measure prices of communications equipment? This paper pursues the following, albeit imperfect, approach. First, I map out the different types of communications equipment and how spending on these different types have changed over the years. The National Income and Product Accounts (NIPA) data for communications equipment is very aggregated, so I use a slew of information from other sources on the types of communications equipment purchased. These data help identify those areas within the communications equipment sector where spending is large and where it has accelerated. This analysis is in the second section of the paper.

The third section presents information from past studies on communications equipment pricing. The fourth and fifth sections of the paper can be viewed as continuations of the "houseto-house combat" to improve price measures used in the NIPAs (see Shapiro and Wilcox (1996)). Section four presents new results on the prices of modems and public telephone exchanges (PBX). The fifth section delves into fiber optic equipment, the area where technological change has been extremely rapid and spending accelerated sharply in the late 1990s and 2000. In the sixth section, the information developed in this paper is combined with the results from elsewhere to come up with several overall price indexes for communications equipment.

Finally, the seventh section addresses how these alternative price indexes would affect growth rates in various investment categories and how calculations on capital deepening and multi-factor productivity (MFP) would change.

\footnotetext{
${ }^{5}$ The communication equipment GDP calculations were performed by using E\&S communication equipment spending and estimates of government and consumer spending. The government and consumer spending estimates were based on the 1992 input-output tables, the last official estimates. The data were further adjusted for imports and exports.
} 


\section{What is Communications Equipment?}

Communications equipment comprises most of the equipment that sends and receives information and the vast array of types of equipment that lies between the sender and receiver. Over time, the types of equipment have multiplied--instead of copper wires connecting homes to central switching offices, equipment now exists that sends information over fiber optic networks, satellites, and cell phone towers, in addition to the equipment that make computer networks run.

How to classify all of this equipment is therefore a daunting task. The Standard Industrial Classification (SIC) system, and the more recent North American Industrial Classification System (NAICS), break down communications equipment into several subcategories: telephone apparatus manufacturing, radio and television broadcasting and wireless communications equipment manufacturing, and other communications equipment manufacturing. Although these categories are useful, over the years there has been movement away from the traditional modes of communication that these systems were based (namely, the land-line telephone system). Indeed, the industry seems to assign communications equipment into much different categories. To help explain what constitutes communications equipment and to help us think about how the types of equipment should be classified, figure 1 presents a simplified diagram of communications networks.

The way to view figure 1 is that information is sent from the left-hand side of the diagram to the right-hand side. The items listed on the left are those pieces of equipment that initially send out a message, and the pieces of equipment listed on the far right are those that receive the message. The items in the middle are the necessary equipment a message must traverse to get from the sender to the receiver. The diagram focuses on voice and data networks and omits radio, TV, alarm systems, walkie-talkies, and defense- specific communications equipment. With that said, the equipment shown in figure 1 makes up the bulk of communications equipment spending.

The elements on the left-hand side are broken into voice and data. The split between voice and data transmission has arisen because a premium has been placed on the quality of the voice network. When a voice message is transmitted, it is essential that each part of that message arrives at its final destination in the correct order and in a timely manner. Therefore, the 
resources devoted to sending a voice message are greater than the resources required for sending a comparably sized data transmission. ${ }^{6}$

On the left side of figure 1, there are three elements under the voice heading and just one element (computer) under the data heading. Each of these systems has evolved somewhat separately, and each has its own protocols and formats. Even as I write this paper, these distinctions are blurring. For instance, cell phones are being used to transfer data (systems such as BlackBerry and Verizon's Express Network), and phone calls can be made over computer networks. With that said, the connections shown in figure 1 represent the routes that a majority of voice and data traffic travels.

Once the information leaves the original sending piece of equipment (phone, cell phone, business phone, or computer), the information is usually sent to a location where information from several sources congregates before being sent on the next leg of its journey. This system is akin to the hub-and-spoke system of the airlines. The hub-and-spoke system is used because it is not economical to have direct connections between everyone on a network to everyone else on a network. Therefore, a good chunk of communications equipment spending is on equipment that takes in many signals and makes and decides where to send the signals to next. Over time, the equipment that performs this routing function has become ever more complex and able to handle greater volumes of information.

Examples of this type of equipment are listed in the middle of figure 1. The upper left portion of figure 1 shows that most home phones are connected to a local telephone-switching center, usually by copper wire. ${ }^{7}$ Cell phones instead send a signal over the airwaves to a base station. The signals in the base station are then sent to a switching center, joining calls made from residences. Phones in businesses, government buildings, and academic institutions are often connected to their own phone network. The two dominant types of equipment that run these networks are called public branch exchange (PBX) and keystone telephone systems (KTS). PBXs and KTSs are then usually connected to switching centers.

In figure 1, the fourth device used to initially transmit information is the computer. Actually, the parts of the computer that are officially considered communications equipment are modems

\footnotetext{
${ }^{6}$ However, as technology improves, the distinction between voice and data transmission will all but disappear. Already, voice over Internet protocol (VOIP) applications are arising. In the IP system, a message is broken into packets, and those packets are then routed to their final destination, although not all of the packets will take the same route.

${ }^{7}$ Switching centers are also referred to as central offices, local central office, exchange, and local exchanges. Also, a home phone may transmit and receive information over its cable TV line.
} 
and local area network (LAN) cards (the most common of which are Ethernet cards). A computer can be linked to larger networks in one of three ways. First, with a traditional analog modem or a digital subscriber line (DSL), a computer can use a copper phone line to connect to a switching center. Second, computers can use cable TV lines. These first two mediums are popular for home computer use. Many business, government, and academic computers are instead linked to a LAN. LANs can then be linked to other LANs, to switching centers (say, via a T1 line), or to wide area networks (WANs).

Switching centers contain various equipment, including telephone equipment, satellite dishes, and the equipment to light up fiber optic networks. A message sent from the right side of figure 1 to the left side may go through many such switch centers. For data communication, a message is broken into packets, and those packets can each take different routes to get to the final destination.

\section{Expenditures}

Figure 1 shows the basic components of the modern communications system. Using data from a very wide variety of sources, table 3 shows estimates of how much was spent on various pieces of equipment. ${ }^{8}$ The data in table 3 come from a very wide array of sources, mainly from private research firms and trade associations. For instance, the data on expenditures on LAN equipment came from Gartner/Dataquest, the data on expenditures for fiber optic equipment came from two firms that follow the industry - and is described in more detail later in the paper-- and data on many of the smaller categories came from various issues of the Multimedia Telecommunications Market Review and Forecast by the Telecommunications Industry Association.

The data in table 3 are only from 1997 to 2000 because those are the years for which I could obtain decent estimates for all major categories. In some of the results that follow, results for individual pieces of equipment go back until the late 1980s and there are some results for 2001.

I chose private and industry sources over government sources for two reasons. First, government statistics do not report the necessary detail on how much is spent on different types of communications equipment. Second, private sources tend to classify communications equipment differently than the SIC and NAICS, and since I have to rely on private sources to estimate price indexes, I chose the categories that the industry uses.

\footnotetext{
${ }^{8}$ The largest omitted categories in table 3 are likely radio equipment (outside of cellular phone equipment), broadcast and studio equipment, and alarm systems.
} 
Most categories experienced growth in nominal spending in the late 1990s. In particular, there was a tremendous surge in spending on fiber optic equipment (the fiber itself is relatively cheap and not considered communications equipment), reflecting a large build-out of the several large new fiber networks. Fiber optic networks and fiber optic equipment is discussed more fully in section $\mathrm{V}$.

Table 3 also shows where the big bucks are spent on communications equipment. Spending on communications equipment is dispersed among many distinct types of products. The largest single major category is switching-center equipment. And within that category, fiber optic equipment made up the bulk of the expenditures in 2000 (in 1997, the share of central office switching equipment was only half as large). This fact is interesting since there have been many reports of the tremendous advances made in fiber optic technology. But just how important those advances are to all of communications equipment does depend on how much is spent on fiber optics.

The bottom of table 3 shows the total expenditures in the categories I've displayed. The bottom of table 3 also shows communications equipment investment as reported in the NIPAs. The sums of my categories are less than the NIPAs because I have excluded a number of categories. However, what is somewhat reassuring is that the data I've tallied has similar growth rates to the NIPA data between 1997 and 2000, and both series show an especially large increase in 2000 .

\section{Previous research on prices of communications equipment}

There has already been research on prices for some of the categories shown in table 3 . In particular, research has been done on cell phones, central office telephone switches, and LAN equipment. Together, these three categories constitute 42 percent of the communications equipment expenditures in 1997 and 36 percent 2000. Because one objective of this paper is to devise a best guess for an overall price index, I'll discuss the previous research with an emphasis on what were the driving forces that lowered prices. The results from the previous studies are summarized in table 4.

\section{Cell Phones}

Jerry Hausman has written a series of papers on the price of cellular telephone service. He cites that when cell phones were first introduced in 1983, they sold for about $\$ 3,000$. By 1997 , they 
sold for about $\$ 200$. These are very rough numbers, and it is certain that the average cellular phone in 1997 had a better feature set than an average phone in 1983. With that said, using the Hausman quotes, prices for cellular phones fell an average of 17.0 percent between 1983 and 1997. One of the primary reasons for the drop in the price of cell phones has been the advances made in semiconductors. Cell phones are quite complex devices, and it has been said that if a cell phone were made with vacuum tubes, the cell phone would have to be the size of the Washington Monument. An additional factor that may help explain the drop in cell phone prices is economies of scale in production of the phones and its components. In 2000, there were an estimated 400 million cell phones sold worldwide.

\section{Telephone Switches}

Kenneth Flamm(1989) and Bruce Grimm (1997) have examined prices of telephone switches. Telephone switches are pieces of equipment usually installed in "switching centers" that route calls from one center to another and then to the final destination. The first telephone switches were electromechanical; these switches physically moved to complete a circuit over which a conversation could be held. In the early 1980s, digital electronic telephone switches performed the same function, but without moving parts. The new switches could perform other functions as well. Bruce used data from the Federal Communications Commission (FCC) to run a hedonic regression where the price of the switch was regressed on a number of explanatory variables. $\mathrm{He}$ found that between 1985 and 1996, prices fell an average of 9.1 percent. However, in the later years of his study, he found that prices fell an average of 16.1 percent.

\section{LAN Equipment}

Chris Forman and I examined the prices of different types of LAN equipment in the second half of the 1990s. LAN equipment is the equipment that sends and routes information over computer networks. The development of this equipment has made accessing the Internet and e-mailing more affordable. Within the LAN equipment aggregate, there are four primary components: LAN cards (the card in a computer that sends and receives information on a computer network), switches (devices that perform simple routing functions), routers (devices that often sit atop computer networks and determine where information packets should be sent), and hubs (pieces of equipment that act as traffic cops in merging information onto a computer network). 
Forman and I found that prices for LAN equipment fell far faster than the BLS comparable PPI would suggest--between 1995 and 2000, the prices for LAN equipment fell at a 17.5 percent annual rate, compared with the comparable PPI that fell only 0.1 percent. As shown in table 4, prices did not fall evenly across the different types of LAN components. ${ }^{9}$

The aforementioned studies found that prices for various types of communications equipment fell, and fell considerably faster over the time periods examined in contrast to the most comparable PPIs. However, making an inference to total communications equipment from these groups is not prudent, as these groups make up just 36 percent of communications equipment spending in 2000. Also, there is a question of whether these studies represent a random sample of communications equipment. They probably do not.

One of the objectives of this section is to provide some evidence that prices for communications equipment fell faster than the official statistics indicate. The studies mentioned before certainly provide some evidence. Some other indirect evidence might also shed light on the issue, namely a measure of the rate of innovation within the communications equipment industry and of the prices for inputs of semiconductors. The first information presented is on patents, and the second set of information comes from Aizcorbe, Flamm, and Khurshid (2002) on price comparisons of semiconductors used in computers versus those used in communications equipment.

A contributing factor to the marvelous improvements in technology has been the rapid pace of scientific discoveries in the fields of computers, communications equipment, and semiconductors. Devising metrics that somehow capture the rate of technological progress is difficult. Two commonly used measures are patents and research and development (R\&D) spending. Unfortunately, R\&D spending figures by industry are not published at a fine enough level of detail (communications equipment, SIC industry 366, is sometimes lumped in with other industries in industry 36, such as semiconductors [SIC industry 367]). However, Manuel Trajtenberg of Tel-Aviv University maintains a database of patents, and those patents are

\footnotetext{
${ }^{9}$ Why did prices of LAN equipment fall so quickly? The reasons are interrelated and speculative, and they include the degree of competition, simplicity of the product, the size of the market, and how many of the devices are made. In terms of competition, prices fell fastest for home and small office routers, the segment of the router market with the most competition (this is the segment where Cisco, the dominant maker of routers, has the smallest market share). One reason for the high level of competition is that designing and producing low-end routers is relatively easy, so that many firms can enter. Also, the quantity of low-end routers allows producers to enjoy economies of scale in production of the routers themselves and in the production of the semiconductors used in the routers. Because of steep competition, prices for switches also fell quickly. Again, although Cisco dominates the market, it did not do so initially.
} 
assigned to classes. Figure 2 shows the percent of total patents that are awarded to three hightechnology fields--computers, communications equipment, and semiconductors--between 1963 and 1999. The share of patents in the computers and peripheral equipment category has been increasing much faster than that of the other two categories. Also, the share of total patents going to communications equipment has been increasing. One wildcard is how the patents for semiconductors are related to chips that are used in computers versus chips that are used in communications equipment.

One reason to think prices for communications equipment have fallen faster than official statistics would indicate is that communications equipment is a large consumer of semiconductors. Aizcorbe, Flamm, and Khurshid have examined the prices of semiconductors by final use category, examining the semiconductor price indexes for semiconductors that go into computers, communications equipment, and so on. They find that the content of semiconductors in communications equipment is about 11 percent. Further, they estimate that in the late 1990s, prices for chips that went into communications equipment fell, on average, about 30 percent per year.

So far I have discussed previous studies on communications equipment prices and some other information that suggests that prices for communications equipment should perhaps be falling faster than the official statistics indicate, but perhaps not as fast as the official numbers for computers. The next two sections present new results on three types of communications equipment to better round out what is actually known about prices.

\section{Modems and PBX/KTS}

Measuring prices for high-tech goods has received a voluminous amount of attention in the past two decades. During this time, several techniques have been employed. Two of the more popular methods are hedonics and match-models. Aizcorbe, Corrado, and Doms (2003) describe these two methods and when these two methods yield numerically similar results. In the results presented below and in the results presented in the next section on prices for fiber optic equipment, matched-model techniques are used. One reason for using matched-model techniques is because the available data is best suited for matched models. For many of the products, I do not have access to all of the performance characteristics to estimate a hedonic model, and I am also constrained by the number of observations. However, as Aizcorbe, Corrado, and Doms demonstrate, the matched model approach yields numerically similar results 
to the hedonic approach when net entry of new products is not large. In most of the results presented in this section and the next, this is indeed the case.

One, albeit small, segment of communications equipment where price information is available for a large number of products is for modems. This first part of this section analyzes modem prices. The second part examines prices for PBX/KTS equipment, the internal phone networks used by many businesses.

\section{Modems}

Although modems are a small part of communication equipment spending, prices for analog modems are relatively easy to obtain because they are sold in the same outlets as personal computers. Examining modems is of interest because there has been tremendous technological change over the past decade. For instance, in late 1991, 9600 baud analog modems were introduced, followed by 14400 baud modems in 1992:Q3, and 28800 baud modems in 1994:Q4. ${ }^{10}$ The rate of increase in speed during this period averaged about 63 percent, a bit less than Moore's law. One might suppose that modems are one type of equipment where prices fell faster than other types of communications equipment because of high competition. Also, it is possible that since most personal computers (PCs) come equipped with modems, firms have been able to achieve higher economies of scale than other segments of the communications equipment industry (modems are similar to LAN cards in many ways).

Our study on modems has two parts. The first part analyzes prices for analog (dial-up) modems for PCs from 1989 to 1998. The second part looks at cable modems from late 1999 to late 2001. There are two modem groups that we do not examine, PCMCIA modems (modems commonly used for laptop computers) and modems used for business applications.

Analog modems. We gathered information on 681 modems from PC World magazine between 1989 and 1998. The reason we stop in 1998 is that finding advertised list prices for modems became more difficult as modems were increasingly offered as standard equipment in computers. For consistency, we obtained prices in ads from Computer Direct Warehouse and Arlington Computer Products, two large retailers of PCs and components that had ads in each issue of PC World that we examined. Manufacturers of the data collected were US Robotics, Hayes, and

\footnotetext{
${ }^{10}$ A 9600 baud modem is not faster than a 1200 baud modem--the 9600 baud modem has higher capacity. The speed of the signals is dictated by the speed of electricity over copper wires, whereas the signal can be modified and refined to have higher capacity. Although engineers cringe when "higher speed" is used to describe various forms of bandwidth, it is likely they have lost the semantic battle.
} 
Practical Peripherals. Our database contains the listed retail price and the speed for each modem. We matched unique modem models across consecutive quarters. On average, each modem was in our sample for seven quarters. We calculated the geometric mean of prices in two consecutive periods.11 Also, we calculated separate price indexes for different classes of modems. For all of the price indexes shown, we required a minimum of six observations. The overall analog modem price index is based on an average of about 100 observations.

A problem with using geometric means is that we are treating each observation equally. If the revenue shares were known for each modem, then we would use that information to construct a matched-model superlative index. If there is a correlation between prices changes and the size of the revenue shares, then the geo-means approach yields biased results. For instance, substitution bias can occur if revenue moves toward those modems where prices are falling relatively rapidly. Unfortunately, we do not know how many of each type of modem was sold, and I could not find any information on this subject.

Our results are shown in figure 3. For comparison, we also place the BEA computer price index on this figure. Our overall modem index falls an average of 15.6 percent over the sample period, compared with the 16.3 percent drop in the BEA computer deflator. Initially, our price index falls more slowly than the BEA computer deflator, when 1200 and 2400 baud modems were commonplace and the 9600 baud modems had not yet been introduced. However, with the advent of 9600 and 14400 baud modems, prices fell more quickly, especially in the case of the 14400 baud modems. Prices continued to fall, although the rate of decline does vary from period to period. Of interest is that prices of the $56 \mathrm{~K}$ modems increased during their first year in our sample and then quickly fell. ${ }^{12}$

Figure 4 highlights modems that are over $10 \mathrm{~K}$ baud. We computed an over-10K-baud index and compared it with a BLS modem index for this category. Our index fell significantly faster than the BLS index: between 1994:Q2 and 1998:Q3, our index fell at an average rate of 15.4 percent, compared with 8.7 percent for BLS.

\footnotetext{
${ }^{11}$ Hedonic regressions could not be run because the advertisements did not provide a complete list of the characteristics of the modems. The advertisements always mentioned the speed and the name of the modem but did not mention any of the other characteristics. For instance, modems vary by the software that is included (such as software that allows the user to use the modem as a fax machine), warranty, speakerphone, mike, caller ID, free tech support, and so on.

${ }^{12} \mathrm{I}$ 'm not sure why this is the case. I read that there was some trouble in using these modems initially, and demand may not have been that high. The $56 \mathrm{~K}$ modems are now standard equipment.
} 
Cable modems. In the past several years, adoption of modems for broadband access (DSL and cable) has increased markedly. We were able to obtain industry-level estimates on revenue and quantities for cable modems between 1999:Q4 and 2001:Q1. The data come from Gartner, a private research firm that tracks a number of high-technology industries. The data we were able to gather are simply the revenue and quantity estimates. According to Gartner, most cable modems are similar in that they must meet the DOCSIS (Data Over Cable Service Interface Specification) standard, the standard that defines "the interface requirements for cable modems involved in high-speed data distribution over cable television system networks" (CableLabs website, 2002). The characteristics of cable modems over this period are fairly uniform, that is, a cable modem in 1999 was not that much different from a cable modem in 2001. Using the Gartner data, the average price of a cable modem fell from \$228 in 1999:Q4 to \$145 in 2001:Q1, an average price decline of 30.4 percent. The results for the cable modems are shown in the upper left of figure $3 .^{13}$

\section{$P B X / K T S$}

My attention now turns to the prices of the phone systems located in many businesses, government offices, and other sites. One reason to examine this segment is that sales of these systems exceeded $\$ 8$ billion in 2000 .

These telephone systems allow users to call one another without using central switching centers. These telephone systems are smart enough to know that when, for instance, you dial a four-digit code, the call you are placing is to another phone within the system. Sometimes on these systems, you have to dial a "9" to get an outside line, that is, a line that is most likely connected to a switching center. These systems fall into two categories: public branch exchanges (PBX) and keystone telephone systems (KTS). A PBX is a bit more sophisticated than $\mathrm{KTS}$ in that the number of phone lines entering a location is less than the number of phones in that location.

PBX and KTS systems have many features, and the feature set has grown over time. Perhaps this isn't surprising. Newer features include call forwarding, call waiting, caller ID, plug-in

\footnotetext{
${ }^{13}$ Cable modems are now being increasingly sold in retail stores. Recent prices (March 2002) for DOCSIS cable modems are about $\$ 100$, a decline of about 30 percent from the year-ago Gartner prices. Only recently are cable and DSL modems sold through retail stores. In 1999 and 2000, cable companies distributed nearly all cable modems.
} 
capability to a T1 line, message centers, and so on. ${ }^{14}$ According to an industry contact, the prices of additional features have been falling over time. However, this contact also said that getting price data would be difficult because prices are usually quoted only after a request for a specific system with specific features has been placed.

I was able to get some data that can produce a bound for prices. Several private firms track the industry and classify PBX/KTS systems by how many lines they have. These firms have revenue estimates for "basic" systems. What exactly constitutes a "basic" system has changed over time, with a "basic" system that is sold today having more features than a "basic" system of five years ago.

The data on revenue and on average prices is presented in table 5 and come from Gartner/Dataquest and appear as they are published. That is, there is no underlying detail that I have access to that is not shown in the table. As shown at the bottom of the table, prices fell an average of 5 percent between 1994 and 2000. Again, I believe that these estimates, based on the Gartner data, to be upper bounds--prices likely fell even faster because the basic configurations improved over time, and my estimates do not pick this up. Just how much are the estimates biased? I don't know. However, a vendor of this equipment believed that prices have fallen in the single digits every year.

\section{Fiber Optics}

The area within communications equipment where the most rapid technological innovations have occurred within the past several decades is fiber optics. Instead of using electrical signals to carry messages over copper wires, there has been an increasing move toward using pulses of light over thin fibers of pure glass. Although there have been improvements in the glass, the most significant innovations have come in the equipment used to transmit and receive the light impulses. In this section, I want to provide a brief overview of fiber optics and then present some information on what has happened to the prices of the equipment used in fiber optic networks.

\footnotetext{
14 There is a trend toward converting traditional circuit-based PBXs to Internet Protocol (IP) technology. A UNIX or NT server would run the phone system instead of a PBX. The phone system would become a computer network, and each phone would have an IP address. Although there has been much talk about this technology, sales of IPbased systems have yet to take off.
} 


\section{Overview of fiber optics}

The use of light in communications has existed for some time, including the use of smoke signals, "one if by land, two if by sea," semaphore, and other visual means when there was direct line of sight. In a development that portended great things to come, Alexander Graham Bell invented the photophone (figure 5). The photophone is basically a mirror that aims a beam of light to a receiver. The source of the light is the sun. The photophone has a device that vibrates a mirror as someone speaks. At the receiving end, a detector picks up the vibrations in the beam of light and converts the vibrations back into voice (analog technology). The sun is not a reliable light source, and the photophone now languishes on the shelves of the Smithsonian Institution. However, using light to carry information has proven to be as revolutionary as the phone itself.

The next big extension of the Bell idea was to transmit light over a medium that didn't have to go into a straight line and didn't require the cooperation of the sun. Between 1850 and 1960, a series of scientific discoveries led to the use of glass fibers, sheathed in various materials, as a medium through which to transmit light. In 1960, the laser was invented. Lasers are able to focus large amounts of light into very tight streams, making them ideal for sending light down a thin glass fiber strand. Refinements in lasers and fibers continued through the 1960s and 1970s, and in 1977 the first field trials were conducted that used fiber optic cables to transmit voice calls in Chicago. There has been near continuous improvement since, especially in terms of the amount of information that can be transmitted by a beam of light and the number of light waves that can be simultaneously sent down a piece of glass fiber.

Fiber optic networks are complex and require many different types of equipment. The basic components of a fiber optic network are the fiber through which the light pulses are sent, a transmitter, a receiver, and a regenerator. As I mentioned before, the fiber itself is not considered communications equipment. A transmitter is a device that takes a signal (perhaps an electrical signal), translates that signal into light pulses, and then sends those light impulses into a piece of glass fiber. Lasers are often used to send the light. Because the capacity of fiber is very high, the transmitter is able to take in many signals simultaneously and translate them all into a single wavelength of light. Taking many signals (tributaries is a word that is used) and 
merging them into a single data stream is called multiplexing. The devices that take in many tributaries to produce one stream of information are called multiplexers. ${ }^{15}$

At the end of the fiber, there is a receiver, called a demultiplexer. ${ }^{16}$ The demultiplexer receives the light signal, converts it into electrical signals, and then sends them out to multiple conduits, the reverse of what happened at the beginning. That's a simplified version of the basics.

In 1996 the basics got a bit more complicated, and exciting. Instead of using one laser to shoot light down a strand of fiber, why not use two or more that operate at different wavelengths and shoot these beams down the fiber simultaneously? One example of the logic behind why this technology works is that when you are in a roomful of people talking, you can sometimes concentrate and just listen to one voice. Your mind acts as a filter and blocks out the other voices. If too many people are talking, and the voices are similar, then hearing a single voice is difficult. Just as the voices have to be different, the wavelengths of the lasers also have to be different. An amazing consequence of this technology (a technology that has been used for a very long time in sending electrical signals down copper wire) is that the capacity of a single piece of fiber instantly increases. This technology is called dense wave division multiplexing (DWDM). The advent of DWDM technology created quite a hoopla, and references are frequently made to the increased capacity of a piece of fiber because of DWDM. In 1996 (when only a small handful of DWDM systems were initially deployed commercially), the maximum amount of information that could be transmitted through a piece of fiber was 2.5 gigabytes per second $(\mathrm{Gb} / \mathrm{s})$. In 2000, DWDM systems could shoot 40 wavelengths, each carrying $2.5 \mathrm{~Gb} / \mathrm{s}$, for a total of $100 \mathrm{~Gb} / \mathrm{s}$. In just four years, DWDMs alone increased the potential capacity of a piece of fiber by a factor of 40, well above the pace of Moore's law.

Figure 6 provides a simplified version of a long haul fiber optic network (most expenditures on fiber and fiber optic equipment in the 1990s were on long-haul networks). The central circle in figure 6 is a fiber ring. Many networks are built using the ring concept--several fibers are used to connect two points so that data can be transmitted in either direction. If the ring is

\footnotetext{
${ }^{15}$ At a point in the process, electrical signals have to be converted to light, and light converted back to electrical signals. The equipment that does this--often the multiplexers--is very expensive. Over the past several years, there has been research on "all optical" networks, networks that would not need the expensive conversion equipment.

${ }^{16}$ Once the pulses of light go merrily down the fiber strand, they begin to disperse somewhat, losing some of the tight form they had initially. This dispersion is called attenuation. At certain intervals, a fiber network may have a "regenerator," a device that reads in the signal, cleans it up, and sends it out again. I was not able to find any information about regenerators, either in terms of expenditures or in terms of prices and characteristics.
} 
severed at one point, the data can be transmitted in the other direction. Various pieces of equipment are used to send and receive information over fiber. A short fiber optic glossary is presented in table 6.

In the late 1990s and into 2000, fairly large expenditures were made on the various pieces of fiber optic equipment. Estimates of these expenditures are presented in table 7, and these estimates came from either three different private firms; Gartner/Dataquest, RHK, and KMI. RHK is a private firm that tracks the telecommunications industry and KMI is also a private firm that specializes in tracking the fiber industry, especially the amount of fiber cable laid.

The table shows that the growth rate in nominal spending on fiber optic equipment has increased at close to a 20 percent annual rate since $1994 .{ }^{17}$ A large ramp up in spending for fiber optic equipment occurred in 1999 and 2000 as a flood of companies rushed into the longhaul fiber optic business; at the end of 2000, there were 11 companies that had more than 10,000 route miles of fiber. Unfortunately, there was a tremendous amount of duplication on the main routes and many of the companies went bankrupt. As a consequence, expenditures on fiber optic gear dropped precipitously in $2001 .^{18}$

\section{Prices of fiber optic equipment}

To reiterate, getting information on prices for fiber optic gear is difficult because there are relatively few firms that make the stuff and the number of customers is fairly limited as well. Consequently, standard price catalogs do not exist. An analyst at RHK, Brian Van Steen, tracks prices and quantities for a large number of pieces of fiber optic gear, and he was kind to share his results for multiplexers and for DWDM equipment. The information for digital cross connects came from Gartner. The results that follow are a series of tables that display that data that was given to me. Each table contains information on a different piece of fiber optic equipment, and price indexes were formed by using a matched model, superlative index number approach. The

\footnotetext{
${ }^{17}$ The fiber optic cable is not classified as communications equipment according to the SIC and NAICS. Also, the cost of the fiber cable itself is relatively cheap. Estimates are that in 1999 and 2000, about $\$ 3$ billion was spent annually on the cable. In contrast, expenditures on the equipment used to transmit and receive information over the cable topped $\$ 22$ billion in 2000 . Also, telecom service providers have to invest in other forms of equipment to get a fiber optic network up and going, including computers.

${ }^{18}$ The advent of DWDM equipment may have hastened the collapse of several long-haul fiber companies. DWDM has increased the potential capacity of a piece of fiber many fold. Therefore, when demand on a certain fiber route increases, it is relatively easy (that is, cheap) to increase the capacity of the existing line instead of lighting up another fiber. Therefore, not as many fibers are needed to transport a given amount of information.
} 
reader can skip ahead several pages to the discussion of table 11 that presents the summary results for fiber optic equipment.

Multiplexers. Multiplexers vary in several dimensions, including the capacity of the signal they produce and their range: ultra long haul (more than 600 kilometers), long haul (60-600 kilometers), or metro (less than 60 kilometers). Through 2000, a plurality of expenditures on multiplexers was for the long-haul add/drop variety. ${ }^{19}$ Table 8 presents quantity, price, and revenue estimates of long-haul add/drop multiplexers by capacity.

As shown at the bottom of table 8, between 1997 and 2001, prices fell an average of 15 percent, with the largest price declines in 2000 and 2001 for the higher capacity models. In the earlier years (1996-1998), prices fell at a more modest pace when, according to industry sources, competition was not very strong; although there are several producers of multiplexers, each market segment was relatively concentrated. ${ }^{20}$ However, in 2000 and 2001, prices fell especially fast, particularly for OC 48 devices, in part because the market was flooded with devices from bankrupt firms and because of increased competition from Cisco. Additionally, as demand fell in 2001, producers cut their prices.

What problems might there be with these results? Generally, the quality of equipment within a capacity category is believed to improve over time. For instance, the size of multiplexers is shrinking and the amount of power they consume is also declining. If there is a bias in the results discussed below, like PBX equipment, it is understating price declines. In my conversations with the analyst that provided the data, I think the bias would be small since the importances of the unobserved characteristics seem small relative to the capacity of the machines.

DWDM. Table 9 presents average prices for two types of DWDM gear, terminals and channel cards. Most DWDM terminals are designed so they can easily expand their capacity, that is, how many wavelengths of light they can transmit. Each wavelength is also referred to as a channel. For each channel, a DWDM terminal needs a channel card. The channel card fits into the DWDM terminal much like expansion cards fit into PCs. If four channel cards are added to a

\footnotetext{
${ }^{19}$ Another characteristic is the protocol that multiplexers use. In the long-haul market, most networks use the synchronous optical network (SONET) protocol. In the metro market, other protocols are more common, like Ethernet.

${ }^{20}$ Unfortunately, I wasn't able to get concentration measures for such tight market definitions.
} 
terminal, then that terminal can transmit four different wavelengths simultaneously. As demand increases, additional channel cards are added as needed. Increasing capacity in this way can be done quickly. For instance, according to KMI, the average DWDM terminal had a maximum capacity of 42 channels, but, on average, only 12 of those channels were used. The sales of cards are quite large--between 1998 and 2001, about 44 percent of DWDM sales was of cards. The remainder of the expenditures was on the terminals themselves and other miscellaneous equipment.

RHK has collected some information on prices for various pieces of DWDM gear, and those are presented in table 9. The first portion of table 9 presents price estimates for a sample of DWDM terminals. The terminals vary by the number of cards they can accept and the capacity of each card. Many other possible configurations exist in the market (such as four-channel systems), but I don't have any information on those. Between 1998 and 2001, prices for this set of terminals fell an average of almost 22 percent. The bottom portion of table 9 presents average prices for a sample of channel cards. Prices for channel cards fell an average of 26 percent.

Digital Cross Connects (DCCs). The smallest of the three fiber optic components in terms of expenditures in 2000 were DCCs. Again, the data used to examine prices in this category is akin to the data for multiplexers and for PBX systems. Therefore, the argument that the estimated price declines are biased upward holds for these categories as well. The data came from Gartner/Dataquest for three types of DCCs: narrowband, wideband, and broadband. The difference between these groups is basically the capacity of the circuits they can tap into. Table 10 shows quantities, revenues, and prices between 1994 and 2000. The far right column shows that price declines for DCCs were generally in the single digits.

\section{Summary of fiber optic prices}

Table 11 presents the summary measures for prices, nominal expenditures, and real expenditures for fiber optic equipment. The price indexes are those that were derived in the previous tables. I extrapolated the price indexes for several years where needed, and those extrapolations are described at the bottom of the table.

Since 1994, fiber optic equipment prices fell an average of 12.4 percent, with the sharpest declines in 2000 and 2001. This result goes against the perception that prices fell dramatically (more dramatically than 12.4 percent a year, at least) for fiber optic equipment, the 
poster child of rapid innovation. However, digging beneath the surface yields some important clues as to why prices fell only an average of 12.4 percent. First, notice that fiber optic equipment prices fell just a bit more than 5 percent a year between 1994 and 1996 (as shown in the top portion of table 11). The relative slow declines in prices in these years is attributable to the relatively mild declines in digital cross connects (and the relatively large nominal share of digital cross connects in those years) and the assumed relatively slow decline in prices for multiplexers. Keep in mind that the price indexes for multiplexers in those years were based on prices falling 6.1 percent, an ad hoc assumption I made. I made this assumption because prices in 1997 and 1998 were estimated to have fallen by that amount. Prices for multiplexers fell much faster in later years as competition and the supply of multiplexers in the second-hand market increased. Industry conditions in the early to mid-1990s were reportedly much more like the conditions in 1997 and 1998 than the conditions in 2000 and 2001.

The second reason why prices for fiber optic equipment didn't fall faster over the 1994-2001 period is that DWDM equipment did not make a significant presence (in terms of nominal expenditures) until 1997. As the nominal share of expenditures moved toward DWDM equipment, the decline in the overall fiber optic price index accelerates. In 2001, DWDM accounted for 37 percent of all fiber optic equipment.

The bottom of table 11 combines the nominal expenditures and the price data to compute indexes of real spending. All of the real expenditures are expressed in 1998 millions of dollars. Between 1994 and 2001, real expenditures on fiber optic equipment increased at an annual rate

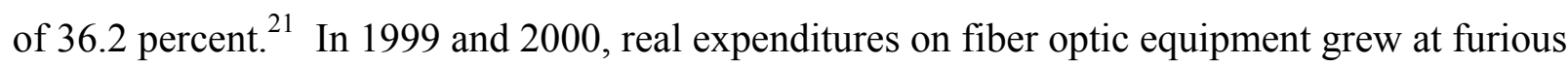
paces, in part due to technological advances and the large build-out of many long-haul networks. In 2001, nominal expenditures plunged over 46 percent, but prices also fell quickly, so that in real terms, expenditures fell a little over 28 percent.

\section{Price indexes for overall communications equipment}

The previous sections presented results on the extent to which prices for various components of communications equipment changed during the 1990s. In this section, those results are used to derive three price indexes for overall communications equipment. The indexes vary by the assumptions that underlie them. The first index is based on very conservative assumptions about

\footnotetext{
${ }^{21}$ Real computer investment increased at an annual rate of 36.5 percent during this period.
} 
price changes and the third index is based on aggressive assumptions about price changes. Hopefully, the "truth" lies somewhere in between the two extreme cases. Like in the previous sections, there are a fair number of tables with a large number of numbers. The three indexes are located on the bottom of tables 14,15 , and 16 .

\section{Aggregate spending and production}

Accurate spending figures are needed to derive aggregate deflators for communications equipment. Table 12 summarizes spending and production of communications equipment. The top panel of numbers in table 12 is from table 3 , spending on communications equipment for certain categories I obtained largely independent of government sources. The second panel of numbers in table 12 shows the official numbers on communications equipment spending. ${ }^{22}$ Using the E\&S, government, and consumer spending figures, total domestic spending on communications equipment grew at an average rate of 14.2 percent between 1997 and 2000, only $1 / 2$ percentage point faster than the figures from table 3 .

Another point to note is the difference in the magnitude of the spending figures in table 3 (line 1) and line 10--the official domestic spending figures are 30 to 40 percent higher than those in table 3. One reason why the domestic spending figures are larger than those in table 3 is that the domestic spending figures include additional items, such as radio equipment (outside of cellular phone equipment), broadcast and studio equipment, and alarm systems.

The bottom portion of table 3 shows estimates of production of communications equipment, a concept similar to the GDP figures in line 4. Surprisingly, industry shipments and product shipments increased at faster rates than the GDP figures. Why this is the case is unclear.

Overall, the point to take away from table 12 is that several independent sources concur that domestic spending on communications equipment increased at a fairly rapid clip in the late 1990s and that production of communications equipment also increased quickly. Further, the spending estimates from table 3 account for a majority of all communications equipment spending.

\footnotetext{
${ }^{22}$ The government and consumer spending figures are not published on a regular basis, and, in fact, were last published for 1992. The government expenditure figures were extrapolated to 2000 by assuming the growth rate was half that of the E\&S series. The consumer spending numbers are based on those I derived in table 3 and on the 1992 input-output tables. Private-sector spending on communications gear likely grew much faster than government spending during the 1990s. As a result of The Telecommunications Act of 1996, a flood of entrants entered into the telecommunication service industry. Also, as stated previously, there was a surge in spending on fiber optic equipment that was tied to the build-out of long-haul fiber networks. These networks are private.
} 


\section{Constructing overall communications equipment price indexes}

I employ a bottom-up approach to construct overall price indexes for communications equipment--the estimates of price indexes for various components of communications equipment are chain weighted. The assumptions made about prices for the conservative, moderate, and aggressive scenarios are displayed in table 13. Tables 14 through 16 show the results based on these assumptions. Table 17 shows a summary of the three sets of results.

Conservative assumptions. Lines 1 through 6 in the top portion of table 14 show the price indexes used in place of the PPI for a select group of products. For the conservative assumptions, only those price indexes are used that were discussed earlier in this paper. That set of results includes previous results on cell phones, central office switching equipment, and LAN equipment. Added to these three sets of results are those that are developed in this paper--fiber optic equipment, PBXs, and modems. For all other communications equipment, the conservative approach uses the PPI for communications equipment. ${ }^{23}$

These price indexes in lines 1 through 6 are chain-weighted using the weights in lines 7 through 12. The aggregate price index for these products, line 15, fall an average of 15.0 percent between 1994 and 2000, with the fastest price declines occurring in the later three years. In contrast, the overall PPI for communications equipment (line 19) falls at a 0.4 percent annual rate.

The price index for the special products does not include the prices for products not listed in lines 1 through 6 . The conservative approach assumes that prices for all other communications equipment follow the PPI. Line 22 shows the overall price index for communications equipment under the conservative assumptions--prices fall an average of 6.4 percent, 6 percentage points faster than the PPI and 6-1/2 percentage points faster than BEA's communications equipment price index (line 24). Recall that the BEA index already makes an adjustment for two of the six product categories in lines 1 through 6--LAN equipment and central office switching and transmission equipment.

\footnotetext{
${ }^{23}$ Ideally each product would be linked to its own PPI. However, I found that a concordance between my system and the SIC was difficult to construct. Also, most PPIs within SIC 366 do not show much change over the late 1990 s, so even if I were to use a more refined concordance, the overall results would not change very much.
} 
Moderate assumptions. The next set of assumptions about prices builds upon the conservative set of assumptions. The first additional assumption made is that prices for cellular phone infrastructure fall half as fast as cell phones. There has been continuous improvement in cell phone technology over the past decade, especially as new generations of equipment have been deployed. There has been a progression from AMPS, iDEN, to GSM and CDMA. ${ }^{24}$ Each successive technology is better than the previous, and this trend is likely to continue.

Another assumption made is that prices for "other data communication" fall about threequarters as fast as LAN equipment. This category includes wide area network equipment, frame relay, ATM, and other components needed to run large data networks. Technology in these areas has improved over the years. However, I do not think it is likely that prices in these categories fell as quickly as it did for LAN equipment. One reason is that the LAN price index was pulled down by LAN cards (fairly simple devices that are mass produced) and switches (an area where there was a lot of competition initially). I do not think that either of these factors existed to the same extent in the "other data communications" equipment area.

Another modification made within the set of moderate assumptions is that PBX prices fall one percent more per year than the results in section IV. As stated previously, the PBX results are likely to be biased upwards. Additionally, I assume that prices for voice processing equipment follow a likewise pattern. There have been large improvements in voice processing technology, especially in the technology used by call centers. This technology basically marries telephone technology with computers; therefore, it would not be surprising if prices fell at a moderate pace.

Finally, for communications equipment not covered by the above mentioned categories, I assume that prices fall at an average annual rate that is 2 percentage points less than the official PPI for communications equipment. In each and every instance that prices for communications equipment have been examined, it has been found that prices fall faster than the PPI. Therefore, assuming that prices fell faster than the officially published numbers by a modest amount seems reasonable.

\footnotetext{
${ }^{24}$ The Advanced Mobile Phone Service (AMPS) was an analog system developed by Bell Labs in the 1970s. The remaining technologies are digital. iDEN, developed by Motorola, uses time division multiple access (TDMA) technology. The two digital technologies that are the fastest growing in the United States are code division multiple access (CDMA) and the global system for mobile (GSM) communications.
} 
Under these assumptions, prices for communications equipment fell at an 8.3 percent annual rate, more than one-third as fast as the BEA computer price index and over 5 percentage points faster than the BEA communications equipment price index.

Aggressive assumptions. Finally, table 16 presents results under the aggressive assumptions. The aggressive assumptions are laid out in table 13. The biggest difference between the aggressive and moderate assumptions is that the PPI is assumed to fall 4 percentage points faster than the official PPI--under the moderate assumptions, the PPI was assumed to fall 2 percentage points faster than the official series.

Under the aggressive assumptions, prices for communications equipment fall at a 10.6 percent annual rate, about two percentage points faster than the moderate assumptions.

\section{Investment and MFP}

In this section we address the implications of the mismeasurement of communications equipment prices. Specifically, we examine how growth rates in various investment aggregates would change if the alternative price indexes for communications equipment are used. The calculations are performed for investment in communications equipment, information processing equipment, and for total nonresidential investment. One reason why we might be interested in how the growth rates of real investment change as a result of new deflators is that it may alter the results on capital deepening and multi-factor productivity (MFP). Later in this section we address this issue.

Basically, the real growth rates of various investment categories will increase as a result of using the price indexes in the previous section. What influences the effect of new communications equipment deflators on various aggregates is the nominal share of communications equipment of the aggregates. Roughly speaking, the effect of altering the price index for communications equipment is proportional to the nominal share of communications equipment. Between 1994 and 2000, communications equipment made up approximately 1/4 percent of all investment in information processing equipment and software and 10 percent of all nonresidential investment.

How the growth rates for real communications equipment, information processing equipment, and total non-residential investment are affected by the conservative, moderate, and aggressive price indexes are displayed in table 18. The figures in table 18 reflect how much the 
average growth rate for those series would increase under the various assumptions about communications equipment pricing.

As shown in the bottom left of the table, if the aggressive deflators are used, then the average annual growth rate for real investment in communications equipment increases by 9.8 percentage points between 1994 and 2000. The effects of the aggressive deflator on information processing equipment and on non-residential investment are smaller, but still considerable. Even if the conservative deflator is used, real non-residential investment would be boosted by 0.4 percentage point per year.

The results in table 18 are averages over 1994 and 2000. Figure 7 shows the data on an annual basis for non residential investment. Each of the lines corresponds to one of the three assumptions about communications equipment prices. As shown, the changes to the deflators have the largest effects for 1997-2000, the period in which nominal spending on fiber optic equipment grew rapidly. In a nutshell, adopting deflators for communications equipment that more likely reflect actual price movements would have non trivial effects on a variety of investment categories.

One reason why the growth rate in real investment is of interest is because of the relationship between real investment, the capital stock, and productivity. This is especially true of the acceleration of productivity in the second half of the 1990s when current estimates suggest that there was a significant contribution from capital deepening and a significant contribution from acceleration in MFP.

One way in which the changes in the growth rate of communications equipment feeds into changes in productivity is the output effect; the growth rate of overall output is increased because of the growth rate of one of the parts has increased. The output effect is small given the small share of communications equipment to total output; the average share of communications equipment to total GDP between 1994 and 2000 is about 0.9 percent, and about 1.1 percent of total non-farm business output. Even if the aggressive results are used, GDP growth would be boosted by less than 0.1 percent per year.

The other way in which the deflators affect productivity is through the contribution to the growth rate of capital services; a higher growth rate in capital services will shift some of the increase from multi factor productivity growth towards capital deepening. One way to estimate the effect changes in capital deepening is by examining the product of the capital income share of communications equipment and the change in the real growth rate in communications 
equipment. Daniel Sichel has estimated that the communication equipment share during the later half of the 1990s is a bit less than 2 percent. The moderate deflators for communications equipment would boost real communications equipment growth by an average of 6-1/2 percent, resulting in capital deepening increasing by a bit more than 0.1 percentage point per year. To put this result in some context, between 1997 and 2000, Daniel Sichel estimates that MFP grew at a 1.1 percent average rate; the moderate results in this paper on communications equipment would likely lower that estimate to closer to 1.0 percent. If the more aggressive assumptions about communications equipment prices were used, then MFP growth would be lowered to closer 0.9 percent per year.

\section{Conclusion}

The view that statistical agencies have difficulty in measuring prices for classes of goods that exhibit rapid technological change has long been espoused. Measuring prices for such goods poses special problems and extra effort has to be employed. For instance, there is now a large and rich literature on measuring prices for computers, and the results of this research have been folded into the national accounts.

Surprisingly, relatively little work on more accurately measuring prices has been done in the area of communications equipment, an area where nominal expenditures have been very close to that of computers and an area where certain segments have enjoyed rapid technological change. There are several reasons for this, including the large diversity of products within communications equipment and the difficulty in obtaining prices.

This paper has attempted to derive measures of prices for communications equipment by gathering information on prices for many of the individual pieces of communications equipment. Some of the price series were poached from previous research, some others were developed more fully in this paper, and some assumptions have been about the remainder. We estimate that prices for communications equipment likely fell anywhere between 5-1/2 to 10-1/2 percent on average between 1994 and 2000, significantly faster than the PPI and the BEA deflator.

On the one hand, these results are somewhat akin to the price profiles for computers in that they show steady declines, and that the declines accelerated in the late 1990s. On the other hand, the price declines for communications equipment appear to be less than half that of computers. We did find that prices for some components of communications equipment fall very fast, especially for fiber optic equipment. However, fiber optic equipment makes up a small share of 
total communications equipment, and so the influence it has on the larger communications aggregate is muted.

Our results are also roughly consistent with several independent sources of information on technological change and price declines. First, Aizcorbe, Flamm, and Khurshid find that the prices for semiconductors that go into communications equipment do not fall as quickly as prices of chips that go into computers. Further, semiconductor content in computers is higher. Second, figure 2 showed that the number of patents awarded to communications equipment was much less than those awarded for computers in the late 1990s.

One can speculate for other reasons why prices for communications equipment do not fall as quickly as computers may because the communications equipment industry is much more fragmented than that for computer hardware. Achieving economies of scale or proceeding up learning curves as are important for computers and semiconductors does not appear to happen often within communications equipment, with the exception of cell phones and LAN cards.

The implications for the results in this paper are that real investment in certain categories was much higher than actually reported. For instance, real nonresidential investment would be from 0.5 to 1.0 percentage point higher between 1997 and 2000 if the deflators presented in this paper were used. This higher rate of real investment also feeds into higher rates of capital accumulation, resulting in shifting a small portion of the growth in MFP in the late 1990s to capital deepening. 


\section{References}

Aizcorbe. A., C. Corrado, and M. Doms (2003) "When Do Mathced-Model and Hedonic Techniques Yield Similar Price Measures," Working Paper, Federal Reserve Bank of San Francisco.

Aizcorbe, A., K. Flamm, and A. Khurshid (2002) "The Role of Semiconductor Inputs in IT Hardware Price Decline: Computers vs. Communications, "FEDS Working Paper 2002-37.

Doms, Mark and Christopher Forman (2003), "Price for LAN Equipment," San Francisco Federal Reserve Working Paper \#

Flamm, Kenneth (1989) "Technological Advance and Costs: Computers versus Communications" in Robert Crandall and Kenneth Flamm, eds. Changing the Rules: Technological Change, International Competition, and Regulation in Communications. Washington: The Brookings Institution. 13-61.

Forman, C. and M. Doms (1999) "Price Declines and Consumer Welfare Benefits in Computer Networking Equipment," Working Paper, Kellogg School of Management, Northwestern University.

Gordon, Robert J. (1990). The Measurement of Durable Goods Prices. National Bureau of Economic Research Monograph.

Grimm, Bruce (1996) “A Quality Adjusted Price Index for Digital Telephone Switches," Working Paper, Burea of Economic Analysis.

Jorgenson, Dale and Kevin Stiroh (2000), "Raising the Speed Limit: U.S. Economic Growth in the Information Age", Brookings Papers on Economic Activity, v.0, pp. 125-211.

Shapiro, M. and D. Wilcox (1996) "Mismeasurement in the Consumer Price Index: An Evaluation," in B.S. Bernanke and J.J. Rotemberg, eds. NBER Macroeconomics Annual. Cambridge, MA: MIT Press.

Telecommunications Industry Association. Multimedia Telecommunications Market Review and Forecast, various years.

Trajtenberg, M. (1989) Economic Analysis of Product Innovation: The Case of CT Scanners. Cambridge, Massachusetts: Harvard University Press.

Triplett, J. (1989) Price and Technical Change in a Capital Good: A Survey of Research on Computers. in D. Jorgenson and R. Landau, eds. Technology and Capital Formation.

Cambridge, MA: MIT Press. 127-213. 
Figure 1. A simplified version of voice and data communication networks

\section{Initial transmission}

Voice

Terminus

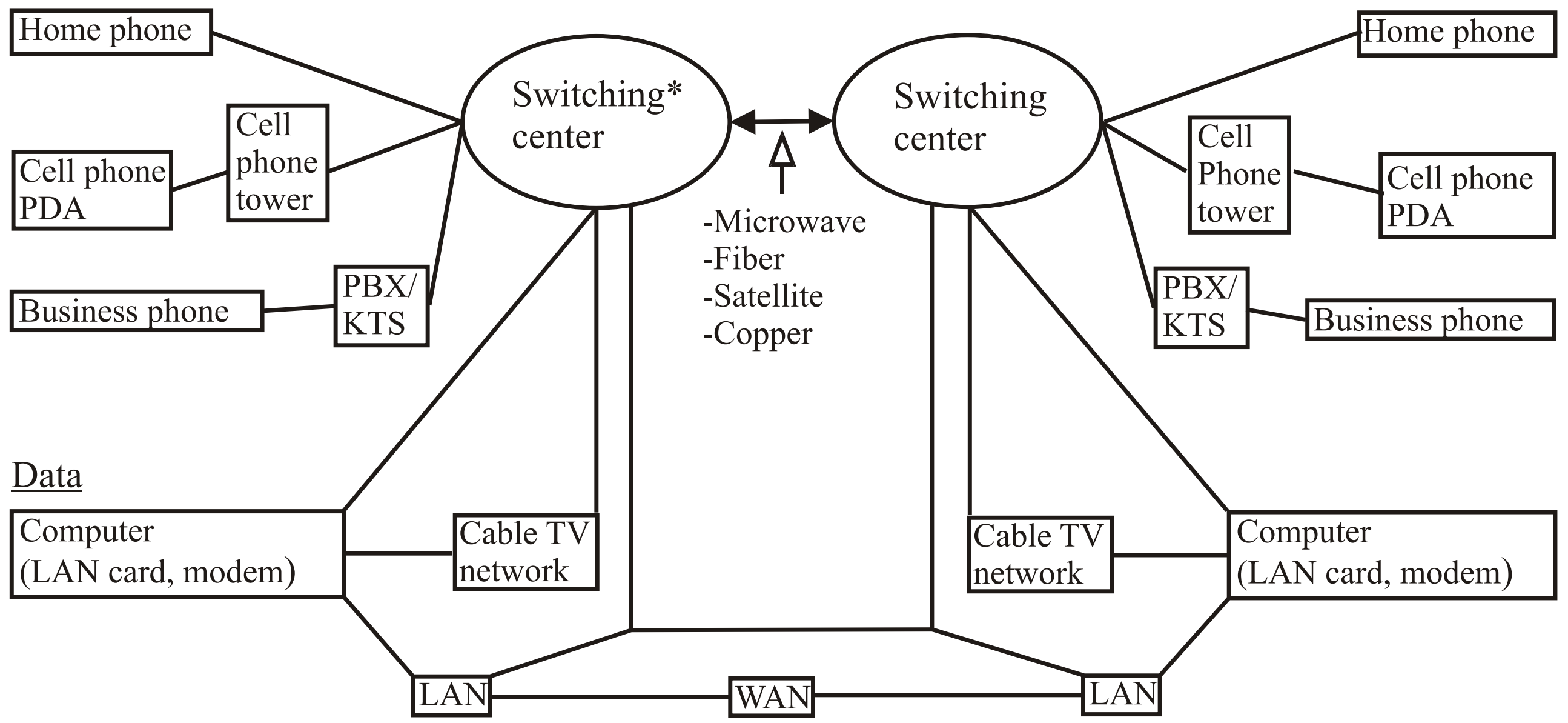

*Equipment in switching centers contain gear that accepts incoming information from many different languages, protocols, and mediums and then decides where to send the information next. This gear includes voice switches and fiber optic equipment.

LAN - local area network.

WAN - wide area network.

PDA - personal digital assistant.
$\mathrm{PBX}=$ public branch exchange.

$\mathrm{KTS}=$ keystone telephone system . 


\section{Figure 2. Share of U.S. patents by high-technology category}

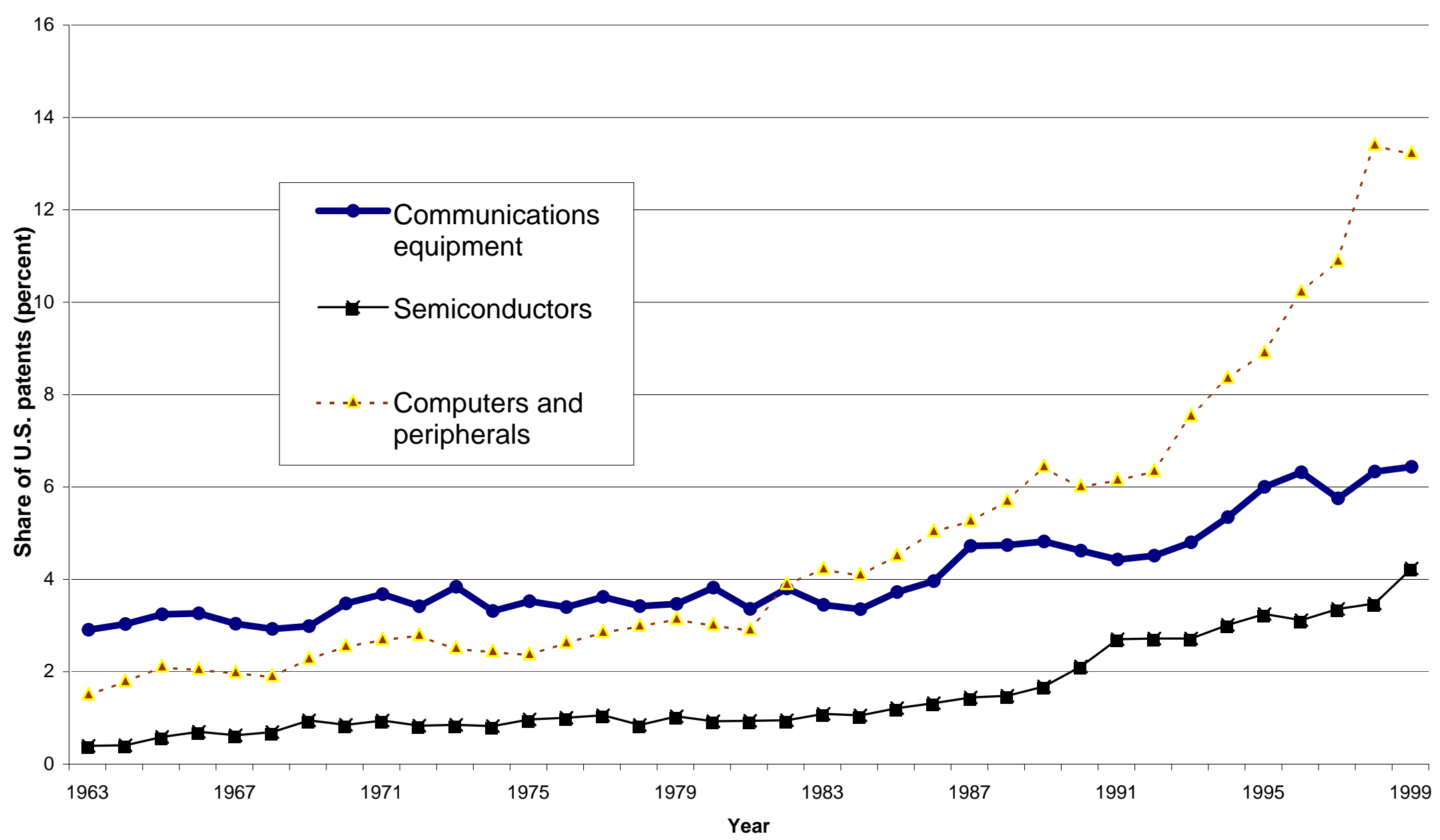

Source: Manuel Trajtenberg

Computers and peripherals=computer hardware and software + computer peripherals + information storage. 


\section{Figure 3: Price Indices For Modems}

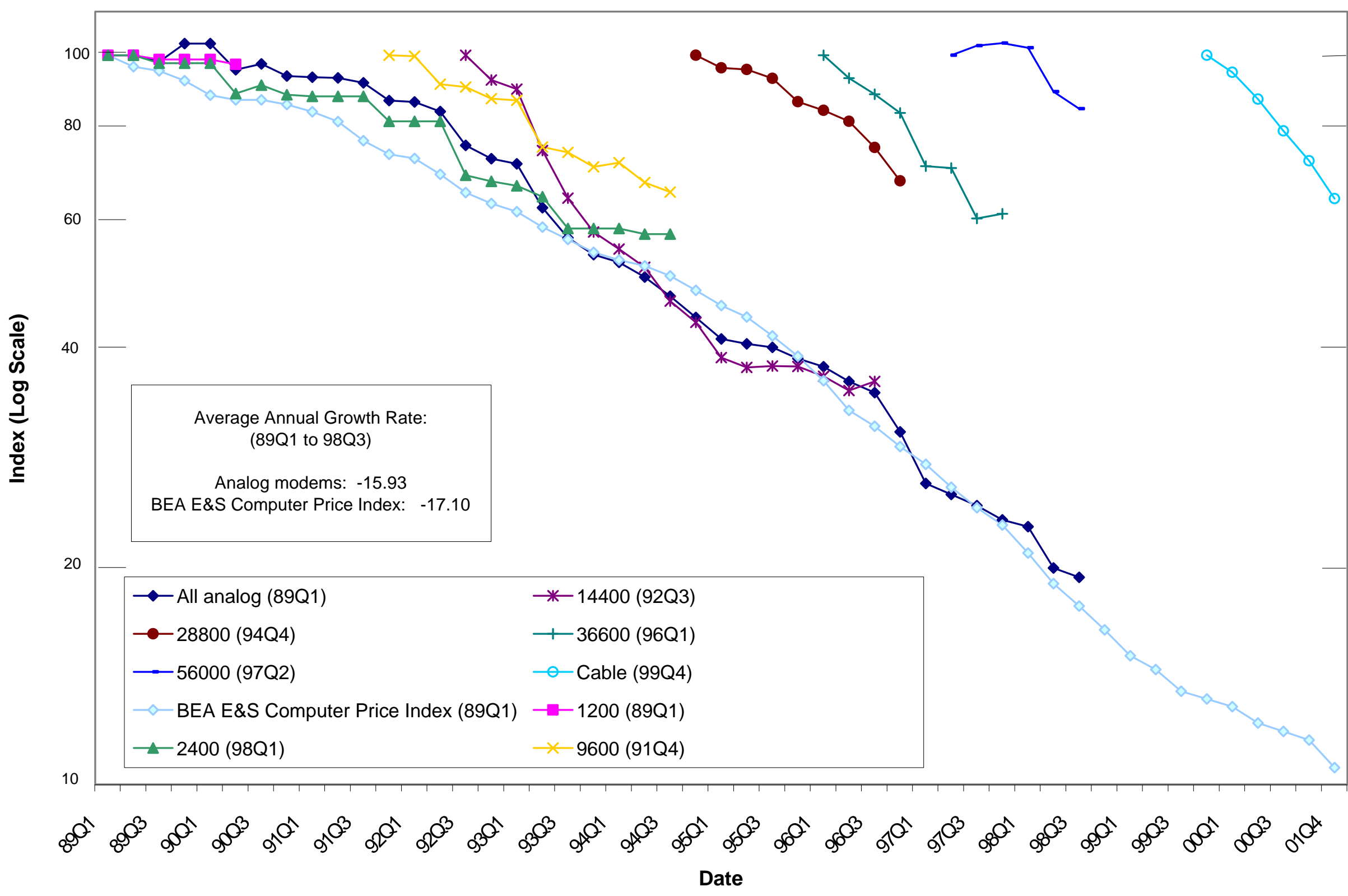

Source: Analog modem data were collected from CDW and ACP advertisements in PC World magazine beginning February, 1989 (Q1). The 681 observations were generally U.S. Robotics, Hayes, and Practical Peripheral models. Cable modem figures (1999Q4 to 2001Q4) were derived from market statistics produced by Gartner, Inc. Computer and communications equipment price data are from BEA. 


\section{Figure 4: Price Indices For Modems over 10K bps}

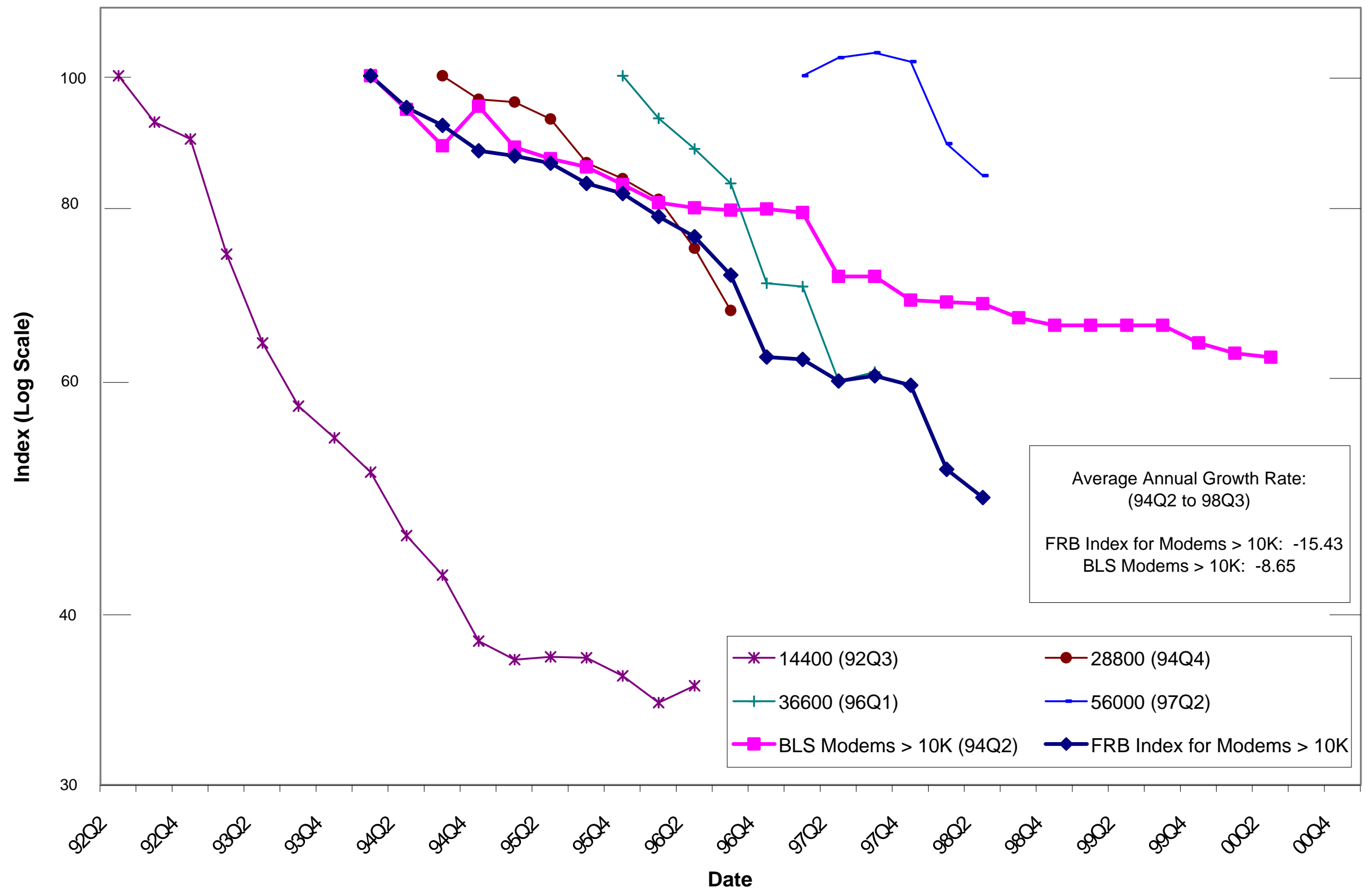

Source: Analog modem data were collected from CDW and ACP advertisements in PC World magazine beginning February, 1989 (Q1). The 681 observations were generally U.S. Robotics, Hayes, and Practical Peripheral models. Cable modem figures (1999Q4 to 2001Q4) were derived from market statistics produced by Gartner, Inc. Computer and communications equipment price data are from BEA. 
Figure 5: Alexander Graham Bell's Photophone

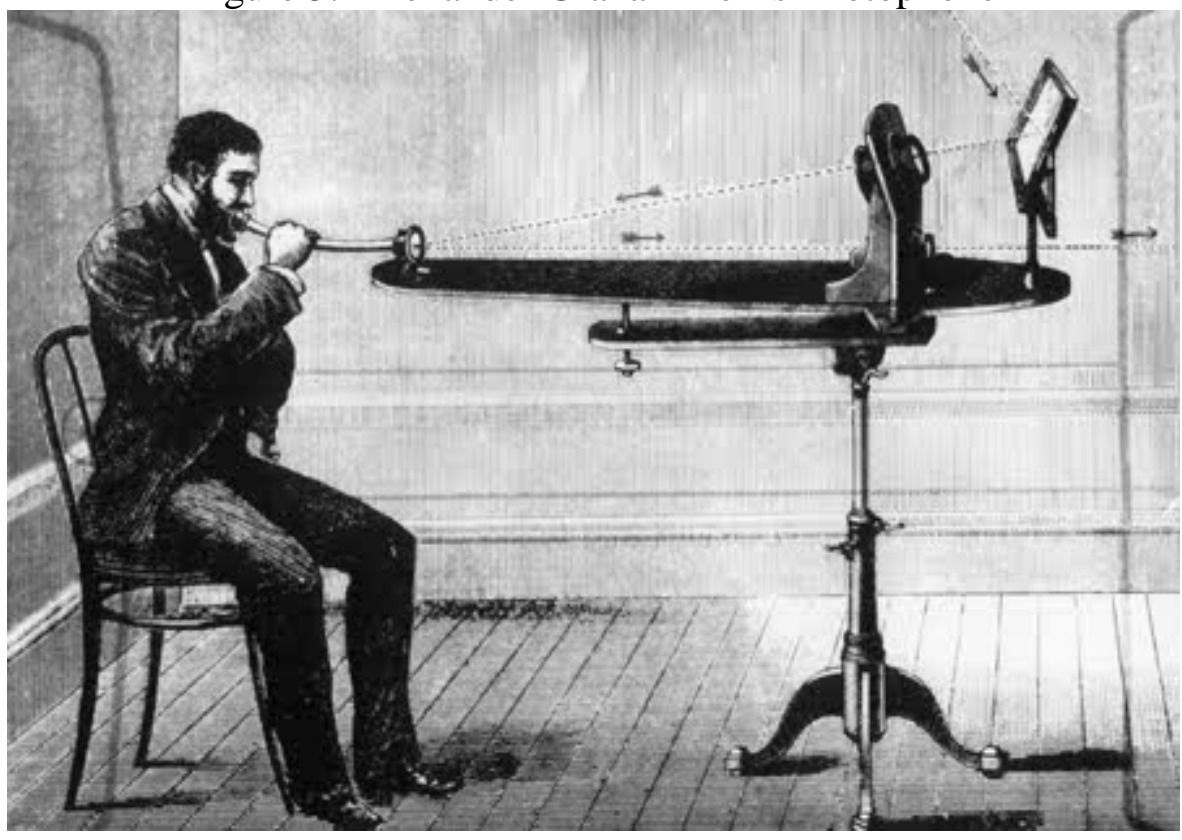


Figure 6 . Basic long-haul fiber optic network

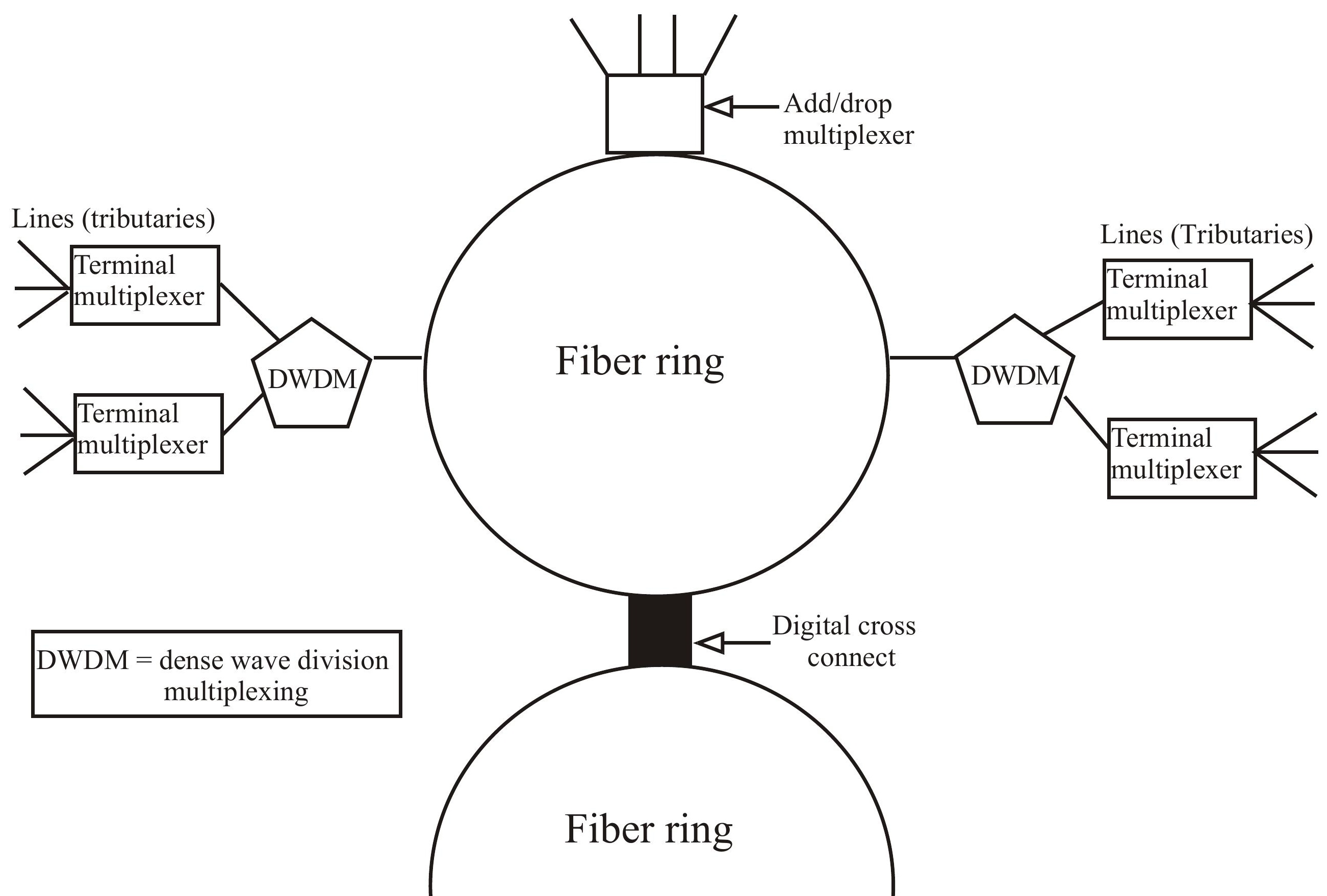


Figure 7: Changes in the real growth rate in non-residential investment under differing assumptions for communications equipment prices

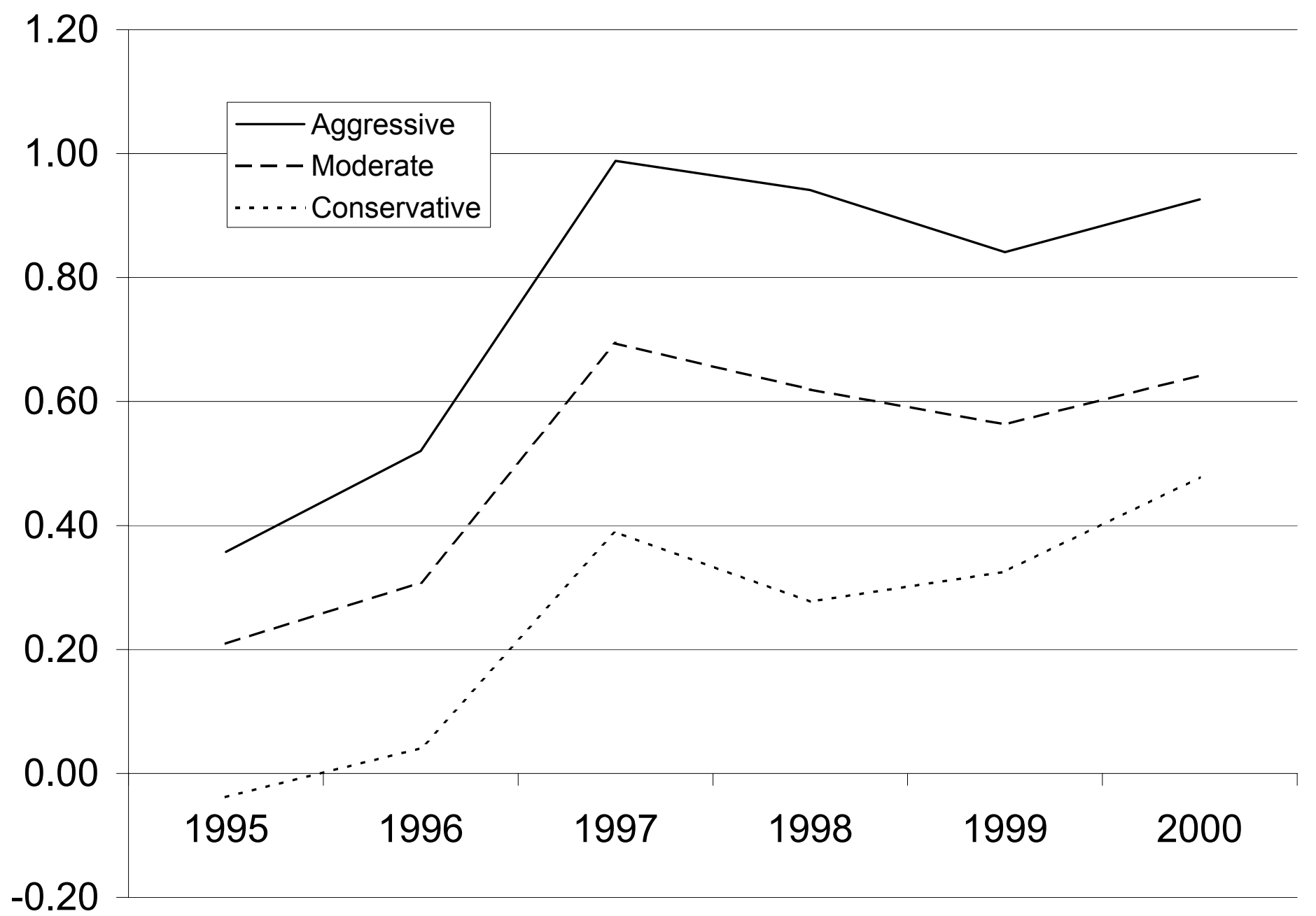


Table 1: Business Investment in Computers and Communications Equipment

\begin{tabular}{|c|c|c|}
\hline & Computers & $\begin{array}{c}\text { Communications } \\
\text { Equipment }\end{array}$ \\
\hline \multicolumn{3}{|c|}{ Average nominal growth in investment (\%) } \\
\hline 1990-1995 & 5.6 & 5.0 \\
\hline $1995-2000$ & 10.6 & 10.5 \\
\hline $1990-2000$ & 8.0 & 7.6 \\
\hline Level of investment, 2000 (\$billions) & 109.3 & 116.8 \\
\hline \multicolumn{3}{|l|}{ Average annual price change (\%) } \\
\hline 1990-1995 & -12.6 & -1.1 \\
\hline $1995-2000$ & -21.6 & -2.9 \\
\hline $1990-2000$ & -17.6 & -2.1 \\
\hline \multicolumn{3}{|l|}{ Average real growth rates (\%) } \\
\hline 1990-1995 & 20.9 & 6.2 \\
\hline $1995-2000$ & 41.0 & 13.8 \\
\hline $1990-2000$ & 31.1 & 9.9 \\
\hline
\end{tabular}


Table 2. GDP and equipment and software (E\&S) growth: contributions of computers and communications equipment

\section{GDP}

1. Growth

2. Contribution of computers

3. Contribution of communications equipment

\section{E\&S}

4. Growth

5. Contribution of computers

6. Contribution of communications equipment
Average annual growth rate (AAGR) (\%)

\begin{tabular}{rrr}
\hline $1990-2000$ & $\frac{1990-1995}{2.22}$ & $\frac{1996-2000}{4.13}$ \\
3.08 & 0.19 & 0.38 \\
0.29 & 0.04 & 0.12
\end{tabular}

9.36

7.15

11.85

2.40

1.94

2.98

0.24

$-0.22$

0.77 


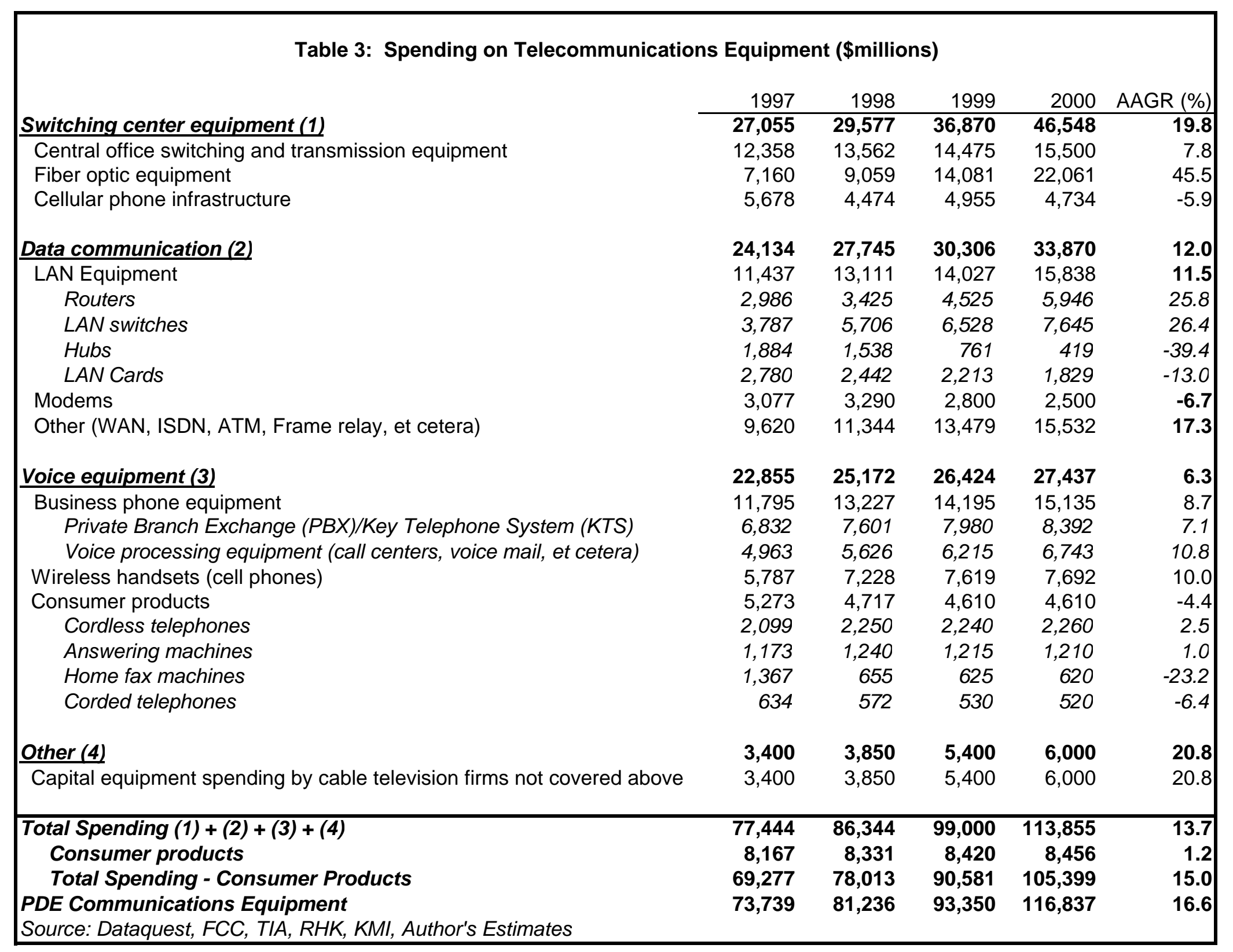


Table 4: Summary of Previous Communications Equipment Price Studies

\begin{tabular}{|c|c|c|c|}
\hline Type of equipment & $\begin{array}{c}\text { Years } \\
\text { examined }\end{array}$ & $\begin{array}{c}\text { Average annual } \\
\text { price decline }(\%)\end{array}$ & $\begin{array}{c}\text { Share of communications } \\
\text { equipment spending in } \\
2000\end{array}$ \\
\hline LAN Equipment & $1995-2000$ & 17.5 & 14.7 \\
\hline LAN cards & $1995-2000$ & 18.3 & \\
\hline Switches & $1996-2000$ & 21.9 & \\
\hline Routers & 1995-1999 & 13.6 & \\
\hline Hubs & $1996-2000$ & 19.0 & \\
\hline Cell Phones & 1983-1997 & 17.0 & 7.2 \\
\hline Telephone switches & 1985-1996 & 9.1 & 14.4 \\
\hline
\end{tabular}




\begin{tabular}{|c|c|c|c|c|c|c|c|c|}
\hline \multicolumn{9}{|c|}{$\begin{array}{r}\text { Table 5: Average Prices and Quantities for PBX Syste } \\
\qquad \underline{\text { Number of lines }}\end{array}$} \\
\hline \multirow{4}{*}{1994} & & 1 to 8 & 9 to 24 & 24 to 48 & 49 to 100 & 101 to 400 & 401 to 1000 & Price Index \\
\hline & Price & 2,701 & 6,856 & 17,226 & 47,806 & 170,511 & 589,428 & 1.00 \\
\hline & Quantity & 190,000 & 99,200 & 50,400 & 27,400 & 5,400 & 1,100 & \\
\hline & Revenue (\$millions) & 513 & 680 & 868 & 1,310 & 921 & 648 & \\
\hline \multirow{3}{*}{1995} & Price & 2,851 & 7,231 & 18,465 & 50,057 & 169,567 & 567,416 & 1.03 \\
\hline & Quantity & 199,200 & 100,600 & 47,200 & 24,600 & 6,300 & 1,200 & \\
\hline & Revenue & 568 & 727 & 872 & 1,231 & 1,068 & 681 & \\
\hline \multirow[t]{3}{*}{1996} & Price & 2,374 & 6,819 & 18,406 & 44,295 & 166,433 & 530,018 & 0.96 \\
\hline & Quantity & 187,814 & 117,311 & 46,759 & 26,863 & 6,982 & 1,298 & \\
\hline & Revenue & 446 & 800 & 861 & 1,190 & 1,162 & 688 & \\
\hline \multirow[t]{3}{*}{1997} & Price & 1,900 & 6,953 & 17,851 & 43,054 & 148,222 & 498,172 & 0.90 \\
\hline & Quantity & 283,544 & 122,099 & 50,570 & 34,798 & 8,366 & 1,553 & \\
\hline & Revenue & 539 & 849 & 903 & 1,498 & 1,240 & 774 & \\
\hline \multirow[t]{3}{*}{1998} & Price & 1,732 & 7,253 & 17,799 & 40,319 & 139,287 & 435,616 & 0.86 \\
\hline & Quantity & 289,765 & 113,446 & 52,744 & 39,974 & 10,696 & 1,769 & \\
\hline & Revenue & 502 & 823 & 939 & 1,612 & 1,490 & 771 & \\
\hline \multirow[t]{3}{*}{1999} & Price & 1,733 & 6,622 & 16,138 & 38,462 & 122,320 & 413,277 & 0.79 \\
\hline & Quantity & 233,233 & 124,369 & 63,167 & 44,283 & 13,898 & 1,842 & \\
\hline & Revenue & 404 & 824 & 1,019 & 1,703 & 1,700 & 761 & \\
\hline \multirow[t]{3}{*}{2000} & Price & 1,996 & 6,424 & 15,550 & 36,393 & 103,316 & 408,678 & 0.75 \\
\hline & Quantity & 228,883 & 96,716 & 57,085 & 36,215 & 15,734 & 1,692 & \\
\hline & Revenue & 457 & 621 & 888 & 1,318 & 1,626 & 691 & \\
\hline \multicolumn{2}{|l|}{ AAGR (\%) } & -4.9 & -1.1 & -1.7 & -4.4 & -8.0 & -5.9 & -4.8 \\
\hline \multicolumn{9}{|c|}{$\begin{array}{l}\text { Sources: U.S. Premise Switching Systems Market Share and Forecast, 2000: Market Statistics, Gartner } \\
\text { Group, Inc May 8, 2000, U.S. Premise Switching Systems Market Share and Forecast, 1999: Market } \\
\text { Statistics, Gartner Group, Inc. April 12, 1999, and U.S. PBX/KTS and PCX Market Share and Forecast, } \\
\text { 2001: Market Statistics Gartner Group, Inc. May 31, } 2001 .\end{array}$} \\
\hline
\end{tabular}




\section{Table 6: Fiber Optic Glossary}

Multiplexer (also known as a "mux"). Devices that can input multiple signals to produce a single signal, and devices that input a single signal and produce multiple signals. An add/drop mux selectively adds and/or drops wavelengths without having to use terminal equipment. A teminal mux extracts all signals/wavelengths from the fiber.

Dense wave division multiplexing (DWDM), also known as wavelength division multiplexing. Equipment that transmits multiple lightwaves down a single piece of fiber. For instance, there are DWDM devices that can send and receive 40 different wavelengths, with each wavelength having a maximum capacity of 2.5 gigabytes per second. A DWDM system of this type could send 100 gigabytes per second.

Digital cross connect, a device that is able perform simple extraction and merging onto a fiber ring.

Regenerator, a device that takes an attenuated optical signal and re-issues the signal in a "cleaner" form. 
Table 7: Nominal Spending of Fiber Optic Equipment (\$ millions)

\begin{tabular}{|c|c|c|c|c|c|c|c|c|c|}
\hline & 1994 & 1995 & 1996 & 1997 & 1998 & 1999 & 2000 & 2001 & AAGR $(\%)$ \\
\hline Total Fiber Optic Equipment & 3,443 & 4,163 & 5,112 & 7,160 & 9,059 & 14,081 & 22,061 & 11,842 & 19.3 \\
\hline (percent change) & & 20.9 & 22.8 & 40.0 & 26.5 & 55.4 & 56.7 & -46.3 & \\
\hline Multiplexers & 1,865 & 2,406 & 2,656 & 3,562 & 4,556 & 7,291 & 10,573 & $4,880.0$ & 14.7 \\
\hline Dense Wavelength Division Multiplexing (DWDM) & 0 & 0 & 381 & 1,595 & 1,854 & 3,427 & 6,740 & 4,348 & 62.7 \\
\hline Digital Cross Connects & 1,111 & 1,182 & 1,455 & 1,581 & 2,210 & 2,749 & 3,950 & $1,914.0$ & 8.1 \\
\hline Other & 467 & 576 & 620 & 422 & 439 & 614 & 799 & 700 & 5.9 \\
\hline
\end{tabular}

Source: RHK, Gartner, KMI. 


\begin{tabular}{|c|c|c|c|c|c|c|c|}
\hline Table 8: Prices ar & uantities $f$ & r Long-Ha & ll Add/Dro & Multiples & ers from $F$ & HK & \\
\hline System Units (thousands) & 1996 & 1997 & 1998 & 1999 & 2000 & 2001 & AAGR $(\%)$ \\
\hline OC3 (155.52 megabits per second) & 3.9 & 5.0 & 7.2 & 8.0 & 9.3 & 10.1 & 24.7 \\
\hline OC12 (622.08 megabits per second) & 2.8 & 3.9 & 5.8 & 6.4 & 8.5 & 6.1 & 32.4 \\
\hline OC48 $(2,488.32$ megabits per second) & 6.1 & 6.5 & 7.6 & 11.7 & 24.0 & 11.0 & 41.0 \\
\hline OC192 (9,953.28 megabits per second) & - & - & 1.5 & 4.5 & 11.3 & 5.8 & 174.5 \\
\hline Total & 12.7 & 15.4 & 22.2 & 30.5 & 53.1 & 33.0 & 43.1 \\
\hline \multicolumn{8}{|l|}{ Revenue (\$ millions) } \\
\hline OC3 & 77.0 & 90.0 & 123.0 & 120.0 & 125.8 & 122.2 & 13.0 \\
\hline OC12 & 132.0 & 154.0 & 216.0 & 210.0 & 254.0 & 165.4 & 17.8 \\
\hline OC48 & 917.0 & 947.0 & $1,039.0$ & $1,398.1$ & $2,302.2$ & 550.0 & 25.9 \\
\hline OC192 & - & - & 599.0 & $1,571.3$ & $3,175.2$ & $1,277.4$ & 130.2 \\
\hline Total & $1,126.0$ & $1,191.0$ & $1,977.0$ & $3,299.4$ & $5,857.2$ & $4,880.0$ & 51.0 \\
\hline \multicolumn{8}{|l|}{ Average Unit Values (\$000s/unit) } \\
\hline OC3 & 20.0 & 18.0 & 17.0 & 15.0 & 13.5 & 12.2 & -9.5 \\
\hline OC12 & 48.0 & 40.0 & 37.0 & 33.0 & 30.0 & 27.0 & $-10 . c$ \\
\hline $0 C 48$ & 151.0 & 145.0 & 136.4 & 120.0 & 96.0 & 50.0 & -19.8 \\
\hline OC192 & - & - & 398.0 & 350.0 & 280.0 & 220.0 & -17.9 \\
\hline \multicolumn{8}{|l|}{ Change in Prices (Percent) } \\
\hline $0 C 3$ & - & -10.0 & -5.6 & -11.8 & -10.0 & -10.0 & -9.5 \\
\hline OC12 & - & -16.7 & -7.5 & -10.8 & -9.0 & -10.0 & -10.9 \\
\hline $0 C 48$ & - & -4.0 & -6.0 & -12.0 & -20.0 & -47.9 & -19.8 \\
\hline OC192 & - & - & - & -12.1 & -20.0 & -21.4 & -17.9 \\
\hline Average & - & -6.1 & -6.1 & -11.9 & -19.2 & -30.3 & \\
\hline $\begin{array}{l}\text { Matched Model Price Index } \\
\text { Source: } R H K\end{array}$ & 1.00 & 0.94 & 0.88 & 0.78 & 0.63 & 0.44 & -15.2 \\
\hline
\end{tabular}


Table 9: Average Prices for Selected Long-haul DWDM Equipment, 1998-2001

\begin{tabular}{|c|c|c|c|c|c|}
\hline Average prices for terminals ( $\$ 000$ 's/terminal) & 1998 & 1999 & 2000 & 2001 & AAGR (\%) \\
\hline WDM terminal (32 channel OC-48 open) & 1,316 & 796 & 652 & 457 & -29.7 \\
\hline WDM terminal (32 channel OC-192 open) & 2,532 & 2,236 & 1,804 & 1,346 & -19.0 \\
\hline WDM terminal (32 channel OC-48 integrated) & 516 & 636 & 524 & 367 & -10.7 \\
\hline WDM terminal (32 channel OC-192 integrated) & 1,412 & 1,436 & 1,164 & 866 & -15.0 \\
\hline WDM terminal (96 channel OC-48 open) & 3,684 & 2,076 & 1,676 & 1,173 & -31.7 \\
\hline WDM terminal (96 channel OC-192 open) & - & 6,396 & 5,132 & 3,842 & -22.5 \\
\hline WDM terminal (96 channel OC-192 integrated) & - & 3,996 & 3,212 & 2,402 & -22.5 \\
\hline WDM terminal (160 channel OC-48 open) & 6,052 & 3,356 & 2,700 & 1,890 & -32.2 \\
\hline WDM terminal (160 channel OC-192 open) & - & 10,556 & 8,460 & 6,338 & -22.5 \\
\hline WDM terminal (160 channel OC-192 integrated) & - & 6,556 & 5,260 & 3,938 & -22.5 \\
\hline Average percent change & & -19.1 & -19.2 & -27.2 & \\
\hline Price index & 1.00 & 0.81 & 0.65 & 0.48 & -21.9 \\
\hline \multicolumn{6}{|l|}{ Average prices for channel cards ( $\$ 000$ 's/card) } \\
\hline OC-48 XCVR Transponder Cards & 37 & 20 & 16 & 11 & -32.9 \\
\hline OC-192 XCVR Transponder Cards & - & 65 & 52 & 39 & -22.5 \\
\hline SONET OC-48 XCVR Line Cards & 18 & 15 & 12 & 8 & -22.4 \\
\hline SONET OC-192 XCVR Line Cards & - & 40 & 32 & 24 & -22.5 \\
\hline Average percent change & & -31.3 & -20.0 & -27.5 & \\
\hline Price index & 1.00 & 0.69 & 0.55 & 0.40 & -26.4 \\
\hline \multicolumn{6}{|c|}{ Actual expenditures on channel cards and terminals (\$millions) } \\
\hline Expenditures on DWDM terminals & 926 & 1,782 & 3,958 & 2,531 & 39.8 \\
\hline Expenditures on channel cards & 928 & 1,645 & 2,782 & 1,818 & 25.1 \\
\hline $\begin{array}{l}\text { Overall chain-weighted DWDM price index } \\
\text { percent change }\end{array}$ & 1.00 & $\begin{array}{r}0.75 \\
-25.0\end{array}$ & $\begin{array}{r}0.60 \\
-19.5\end{array}$ & $\begin{array}{r}0.44 \\
-27.3\end{array}$ & -24.0 \\
\hline
\end{tabular}

Source: RHK. For DWDM terminals, "Open" means that the mux is not par of the box, whereas integrated means the mux and the DWDM are in the same unit. An advantage of an "open" systems that you can use equipment from different vendors. An advantage of integrated systems is that they are cheaper and use less power. 
Table 10

\section{Units (thousands)}

Narowband (T1 ports)

Wideband (T3 ports)

Broadband (T3 ports)

\section{Revenue (\$ millions)}

Narowband

Wideband

Broadband

Total

\section{Average price (\$000s/unit)}

Narowband

Wideband

Broadband

\section{Change in prices (percent)}

Narowband

Wideband

Broadband

Total

Quantities, Revenues and Prices for Digital Cross Connects (DCC)

\begin{tabular}{rrrrrrrr}
1994 & 1995 & 1996 & 1997 & 1998 & 1999 & 2000 & AAGR $(\%)$ \\
\hline 440.3 & 429.9 & 452.5 & 419.5 & 490.9 & 601.6 & 902.4 & 12.7 \\
31.5 & 38.2 & 48.5 & 97.0 & 188.7 & 209.2 & 311.7 & 46.5 \\
44.5 & 51.8 & 79.1 & 52.2 & 61.6 & 74.6 & 110.4 & 16.4 \\
& & & & & & & \\
367.7 & 363.0 & 382.0 & 346.1 & 402.4 & 490.3 & 606.6 & 8.7 \\
350.0 & 401.1 & 487.0 & 916.7 & $1,722.0$ & $1,903.7$ & $2,504.7$ & 38.8 \\
376.2 & 394.0 & 550.1 & 339.2 & 388.0 & 448.0 & 601.0 & 8.1 \\
$1,093.9$ & $1,158.1$ & $1,419.1$ & $1,602.0$ & $2,512.4$ & $2,842.0$ & $3,712.3$ & 22.6
\end{tabular}

Digital Cross Connet Price Index

\subsection{4}

11.11

8.45
0.84

10.50

7.61

0.84

10.04

6.95

0.83

9.45

6.50

0.82

9.13

6.30

0.81

9.10

6.01

0.67

8.04

5.44

$-17.5$

$-11.7$

$-9.4$

$-12.3$

Narrowband--DCC equipment designed to electronically cross-connect and manage DS0s (64 Kbps).

Wideband--DCC equipment designed to electronically cross-connect and manage DSs or T1s.

Broadband--DCC equipment designed to electronically cross-connect and manage DS3s/T3s or SONET OC1 circuits.

Source: North American Transmission Equipment Market Share and Forecast, 1999, Gartner, October 11, 1999 
Table11: Summary Indexes for Fiber Optic Equipment

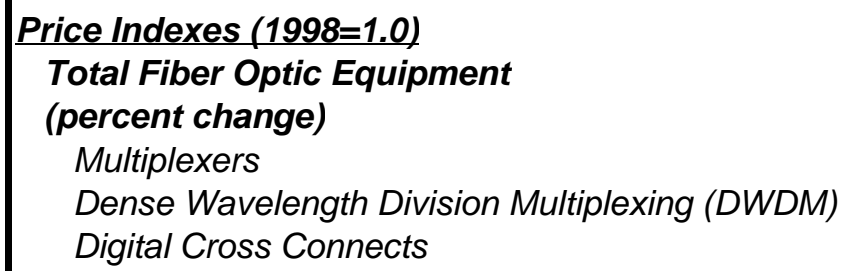

\begin{tabular}{|c|c|c|c|c|c|c|c|c|}
\hline 1994 & 1995 & 1996 & 1997 & 1998 & 1999 & 2000 & 2001 & AAGR (\%) \\
\hline \multirow[t]{2}{*}{1.36} & 1.28 & 1.21 & 1.10 & 1.00 & 0.87 & 0.72 & 0.54 & -12.4 \\
\hline & -5.7 & -5.3 & -9.0 & -9.3 & -12.6 & -17.9 & -25.2 & \\
\hline \multirow[t]{2}{*}{1.29} & 1.21 & 1.13 & 1.07 & 1.00 & 0.88 & 0.71 & 0.50 & -12.7 \\
\hline & & 1.73 & 1.32 & 1.00 & 0.75 & 0.60 & 0.44 & -17.8 \\
\hline 1.20 & 1.14 & 1.09 & 1.03 & 1.00 & 0.99 & 0.87 & 0.80 & -5.6 \\
\hline \multirow[t]{2}{*}{3,443} & 4,163 & 5,112 & 7,160 & 9,059 & 14,081 & 22,061 & 11,842 & 19.3 \\
\hline & 20.9 & 22.8 & 40.0 & 26.5 & 55.4 & 56.7 & -46.3 & \\
\hline 1,865 & 2,406 & 2,656 & 3,562 & 4,556 & 7,291 & 10,573 & 4,880 & 14.7 \\
\hline 0 & 0 & 381 & 1,595 & 1,854 & 3,427 & 6,740 & 4,348 & 41.6 \\
\hline 1,111 & 1,182 & 1,455 & 1,581 & 2,210 & 2,749 & 3,950 & 1,914 & 8.1 \\
\hline \multirow[t]{2}{*}{2,536} & 3,251 & 4,217 & 6,491 & 9,059 & 16,112 & 30,762 & 22,089 & 36.2 \\
\hline & 28.2 & 29.7 & 53.9 & 39.6 & 77.9 & 90.9 & -28.2 & \\
\hline \multirow[t]{2}{*}{1,449} & 1,991 & 2,341 & 3,343 & 4,556 & 8,277 & 14,847 & 9,835 & 31.5 \\
\hline & & 220 & 1,212 & 1,854 & 4,571 & 11,172 & 9,914 & 72.3 \\
\hline 928 & 1,037 & 1,340 & 1,535 & 2,210 & 2,777 & 4,550 & 2,396 & 14.5 \\
\hline
\end{tabular}

\section{Nominal Spending (\$millions) \\ Total Fiber Optic Equipment}

(percent change)

Multiplexers

Dense Wavelength Division Multiplexing (DWDM)

Digital Cross Connects

\section{Real Spending (1998 \$millions)}

Total Fiber Optic Equipment

(percent change)

Multiplexers

Dense Wavelength Division Multiplexing (DWDM)

Digital Cross Connects

Notes: It is assumed that prices for multiplexers fell an average of 6.1 percent in between 1994 and 1996 , the same rate as was estimated for 1996 to 1998.

The price index for DWDM equipment is assumed to fall 24 percent, the average rate from 1998 to 2001.

The price index for digital cross connects in 2001 is assumed to fall 8.0 percent, a slightly faster rate than in previous years because of increased competition in the industry. 
Table 12: Communications Equipment, Spending and Production (\$millions)

\section{Categories from table 3}

1. Total

2. Consumer

3. Business and government spending

\section{GDP accounting}

4. Communications equipment GDP $(5+6+7+8-9)$

5. E\&S

6. Government

7. Consumer spending

8. Exports

9. Imports Memo:

10. Domestic spending $(5+6+7)$

11. (10-1)

\section{ASM production information}

12. Industry shipments

13. ASM product shipments

\begin{tabular}{|c|c|c|c|c|c|c|c|}
\hline \multirow[t]{4}{*}{1994} & 1995 & 1996 & 1997 & 1998 & 1999 & 2000 & $\begin{array}{l}1997-2000 \\
\text { AAGR (\%) }\end{array}$ \\
\hline & & & 77,444 & 86,344 & 99,000 & 113,855 & 13.7 \\
\hline & & & 8,167 & 8,331 & 8,420 & 8,456 & 1.2 \\
\hline & & & 69,277 & 78,013 & 90,581 & 105,399 & 15.0 \\
\hline 69,598 & 77,401 & 83,740 & 97,461 & 103,176 & 110,710 & 124,249 & 8.4 \\
\hline 54,743 & 60,019 & 65,609 & 73,700 & 81,200 & 93,300 & 116,800 & 16.6 \\
\hline 12,914 & 13,533 & 14,157 & 15,017 & 15,771 & 16,919 & 18,983 & 8.1 \\
\hline 4,523 & 4,958 & 5,420 & 8,167 & 8,331 & 8,420 & 8,456 & 1.2 \\
\hline 11,237 & 13,762 & 14,469 & 17,683 & 18,209 & 20,008 & 23,284 & 9.6 \\
\hline 13,819 & 14,871 & 15,915 & 17,105 & 20,335 & 27,937 & 43,274 & 36.3 \\
\hline 72,180 & 78,510 & 85,186 & 96,883 & 105,302 & 118,639 & 144,239 & 14.2 \\
\hline & & & 27,606 & 27,289 & 28,058 & 38,839 & 12 \\
\hline 48,052 & 58,499 & 68,232 & 82,852 & 86,119 & 97,953 & 119,329 & 12 \\
\hline 48,440 & 55,431 & 63,968 & 78,142 & 81,932 & 92,715 & 107,921 & 11.4 \\
\hline
\end{tabular}




\section{Table 13: Three Sets of Assumptions for Prices by Equipment Type}

\begin{tabular}{|c|c|c|c|c|}
\hline Equipment Type & Conservative & Moderate & Aggressive & Comments \\
\hline $\begin{array}{l}\text { Central office switching and } \\
\text { transmission equipment }\end{array}$ & $\begin{array}{l}\text { BEA (16.1 percent } \\
\text { decline per year) }\end{array}$ & BEA & $\mathrm{BEA}$ & \\
\hline Fiber optic equipment & section $V$ results & section $V$ results & section $V$ results & \\
\hline Cellular phone infrastructure & PPI & $\begin{array}{l}-7.5 \text { percent per year, half } \\
\text { that of cellular phones }\end{array}$ & $\begin{array}{l}-10 \text { percent per year, two- } \\
\text { thrids that of cellular } \\
\text { phones }\end{array}$ & $\begin{array}{l}\text { There has been continuous improvement in cell phone } \\
\text { technology over the past decade and there has been increased } \\
\text { competition in the base station equipment market. }\end{array}$ \\
\hline LAN Equipment & Doms and Forman & Doms and Forman & Doms and Forman & \\
\hline Modems & section IV results & section IV results & section IV results & \\
\hline $\begin{array}{l}\text { Other data communications (WAN, } \\
\text { ISDN, ATM, Frame relay, ...) }\end{array}$ & PPI & $3 / 4$ of Doms and Forman & $3 / 4$ of Doms and Forman & $\begin{array}{l}\text { The prices for equipment in this category probably do not fall as } \\
\text { fast as LAN equipment because the market is more dispersed } \\
\text { and competition is not as great. }\end{array}$ \\
\hline $\begin{array}{l}\text { Private Branch Exchange (PBX)/Key } \\
\text { Telephone System (KTS) }\end{array}$ & section IV results & $\begin{array}{l}\text { section IV results-1 } \\
\text { percent per year }\end{array}$ & $\begin{array}{l}\text { section IV results-2 percent } \\
\text { per year }\end{array}$ & $\begin{array}{l}\text { It is likely the results in section IV understate the actual price } \\
\text { declines, so the moderate and aggressive assumptions make } \\
\text { adjustments. }\end{array}$ \\
\hline $\begin{array}{l}\text { Voice processing equipment (call } \\
\text { centers, voice mail,..) }\end{array}$ & PPI & $\begin{array}{l}\text { section IV results for PBX - } \\
1 \text { percent per year }\end{array}$ & $\begin{array}{l}\text { section IV results- } 2 \text { percent } \\
\text { per year }\end{array}$ & $\begin{array}{l}\text { There have been large improvements in technology in this } \\
\text { category during the 1990s, especially in the technology used in } \\
\text { call centers. }\end{array}$ \\
\hline Wireless handsets (cell phones) & Hausman & Hausman & Hausman & \\
\hline $\begin{array}{l}\text { Capital equipment spending by cable } \\
\text { television firms not covered above }\end{array}$ & PPI & $\begin{array}{l}\text { decline of } 5 \text { percent per } \\
\text { year }\end{array}$ & $\begin{array}{l}\text { decline of } 5 \text { percent per } \\
\text { year }\end{array}$ & $\begin{array}{l}\text { There has been improvements in cable TV technology, including } \\
\text { the wide spread upgrades to digital cable. }\end{array}$ \\
\hline $\begin{array}{l}\text { Communications equipment not } \\
\text { covered by above categories }\end{array}$ & PPI & PPI-2 percent per year & PPI-4 percent per year & $\begin{array}{l}\text { The moderate and aggressive cases assume that the PPI for } \\
\text { other categories are mismeasured. However, the largest } \\
\text { components in this group are not the groups where technology } \\
\text { change has been as rampant as other categories. Therefore, the } \\
\text { aggressive case has the PPI falling less than half as fast as the } \\
\text { aggregate price index for the above listed items. }\end{array}$ \\
\hline
\end{tabular}


Table 14: Price Indexes For Communications Equipment--Conservative Assumptions

(all price indexes=1.00 in 1994, all spending figures in \$millions)

\section{Price indexes used instead of the PPI}

1. Central office switching and transmission equipment

2. Fiber optic equipment

3. LAN equipment

4. Modems

5. Private branch exchange (PBX)/Key telephone system (KTS)

6. Wireless handsets (cell phones)

\begin{tabular}{|c|c|c|c|c|c|c|c|}
\hline 1994 & 1995 & 1996 & 1997 & 1998 & 1999 & 2000 & AAGR (\%) \\
\hline 1.00 & 0.84 & 0.70 & 0.59 & 0.50 & 0.42 & 0.35 & -16.1 \\
\hline 1.00 & 0.94 & 0.89 & 0.81 & 0.74 & 0.64 & 0.53 & -10.1 \\
\hline 1.00 & 0.84 & 0.77 & 0.64 & 0.46 & 0.38 & 0.33 & -17.0 \\
\hline 1.00 & 0.83 & 0.72 & 0.51 & 0.41 & 0.29 & 0.20 & -23.3 \\
\hline 1.00 & 1.03 & 0.96 & 0.90 & 0.86 & 0.79 & 0.75 & -4.8 \\
\hline 1.00 & 0.85 & 0.72 & 0.61 & 0.52 & 0.44 & 0.38 & -15.0 \\
\hline 9,677 & 9,810 & 11,537 & 12,358 & 13,562 & 14,475 & 15,500 & 8.2 \\
\hline 3,443 & 4,163 & 5,112 & 7,160 & 9,059 & 14,081 & 22,061 & 36.3 \\
\hline 5,828 & 7,808 & 10,502 & 11,437 & 13,111 & 14,027 & 15,838 & 18.1 \\
\hline 2,500 & 3,000 & 3,500 & 3,077 & 3,290 & 2,800 & 2,500 & 0.0 \\
\hline 5,890 & 6,105 & 6,245 & 6,832 & 7,601 & 7,980 & 8,392 & 6.1 \\
\hline 2,963 & 3,704 & 4,630 & 5,787 & 7,228 & 7,619 & 7,692 & 17.2 \\
\hline 1,481 & 1,852 & 2,315 & 2,894 & 3,614 & 3,810 & 3,846 & 17.2 \\
\hline 28,820 & 24,930 & 28,709 & 32,320 & 37,126 & 43,146 & 52,299 & 10.4 \\
\hline 1.00 & 0.89 & 0.79 & 0.67 & 0.56 & 0.48 & 0.40 & -14.0 \\
\hline 1.00 & 0.85 & 0.72 & 0.61 & 0.52 & 0.44 & 0.38 & -15.0 \\
\hline \multirow[t]{2}{*}{1.00} & 0.89 & 0.79 & 0.68 & 0.57 & 0.48 & 0.41 & -13.9 \\
\hline & -11.3 & -10.9 & -14.6 & -16.3 & -15.3 & -15.2 & \\
\hline \multirow[t]{2}{*}{1.00} & 1.01 & 1.01 & 1.02 & 1.01 & 1.00 & 0.97 & -0.4 \\
\hline & 0.5 & 0.9 & 0.6 & -0.6 & -1.7 & -2.3 & \\
\hline 38,837 & 48,621 & 51,057 & 56,397 & 59,845 & 67,074 & 83,483 & 13.6 \\
\hline \multirow[t]{2}{*}{1.00} & 0.96 & 0.92 & 0.87 & 0.80 & 0.74 & 0.67 & -6.4 \\
\hline & -4.5 & -3.6 & -5.8 & -7.7 & -8.1 & -8.4 & \\
\hline \multirow[t]{2}{*}{1.00} & 0.96 & 0.94 & 0.93 & 0.89 & 0.86 & 0.83 & -3.0 \\
\hline & -4.0 & -2.5 & -1.0 & -4.1 & -3.6 & -2.8 & \\
\hline
\end{tabular}

Spending on the above products

7. Central office switching and transmission

8. Fiber optic equipment

9. LAN equipment

10. Modems

11. Private branch exchange (PBX)/Key telephone system (KTS)

12. Wireless handsets (cell phones)

13. Spending on special products by consumers

14. Spending on special products by business and government

\section{Aggregate price indexes for above products}

15. Total

16. Consumer products

17. Business and government investment

18. percent change

\section{Construction of business and government price index}

19. PPI for communications equipment

20. percent change

21. Business and government spending net of special products

22. Conservative communications equipment price index

23. percent change

24. BEA communications equipment price index

25. percent change 
Table 15: Price Indexes For Communications Equipment--Moderate Assumptions

(all price indexes=1.00 in 1994, all spending figures in \$millions)

\section{Price indexes used instead of the PPI}

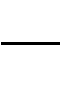

Items from conversative assumptions page with adjustment for

1. PBX prices falling an additional 1 percent per year

2. Other data commnication

3. Voice processing equipment (call centers, voice mail,..)

4. Cellular phone infrastructure

5. Cable TV equipment

$$
1994
$$

1995

1996

1997

1998

1999

2000

AAGR $(\%)$

\section{Spending on special products}

6. Items from conversative assumptions page

7. Other data commnication

8. Voice processing equipment (call centers, voice mail,..)

9. Cellular phone infrastructure

10. Cable TV equipment

11. Spending on special products by business and government

1.00
1.00
1.00
1.00
1.00

0.88

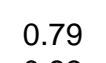

1.03

0.79
0.83

0.83
0.96

0.93

0.86

1.00

0.95

0.90

0.67
0.72

0.72

0.90

0.79

0.86

0.56
0.57

0.57

0.86

0.86
0.73

0.81

\subsection{7}

0.49

0.79

0.68

0.77

0.40
0.44
0.75

0.75

0.63

0.74

\section{8,820}

4,902
4,279

24,930

28,709

32,320

37,126

6,567

8,834

9,620

11,344

4,279

4,435

4,537

4,963

11,344
5,626

43,146

13,479

13,479
6,215

2,554

4,693

5,162

5,678

4,474

3,850

43,435

50,332

55,981

62,420

4,955

5,400

73,195

52,299

15,532

6,743

4,734

6,000

85,308

\section{Aggregate price indexes for special products}

12. Business and government investment

13. percent change

0.91
-9.4

0.83
-8.8

0.73
-12.0

0.62
-14.5

0.54

$-12.9$

0.48

$-12.1$

\section{Construction of business and government price index}

Assume PPI falls 2 percent per year faster than actual

14. Modified PPI for communications equipment

15. Moderate communications equipment price index

16. percent change

17. BEA communications equipment price index

0.96

0.94

0.93

0.89

0.86

3.86

24.0

$-22.5$

$-23.8$




\section{Table 16: Price Indexes For Communications Equipment--Aggressive Assumptions}

(all price indexes=1.00 in 1994, all spending figures in \$millions)

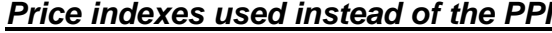

1. Central office switching and transmission equipment

2. Fiber optic equipment

3. Cellular phone infrastructure

4. LAN equipment

5. Modems

6. Other data commnication

7. Private branch exchange (PBX)/Key telephone system (KTS)

8. Voice processing equipment (call centers, voice mail,..)

9. Cellular phones

10. Cable TV equipment

\begin{tabular}{cc}
1994 & 1995 \\
\hline 1.00 & 0.84 \\
1.00 & 0.94 \\
1.00 & 0.90 \\
1.00 & 0.84 \\
1.00 & 0.83 \\
1.00 & 0.88 \\
1.00 & 1.01 \\
1.00 & 1.01 \\
1.00 & 0.85 \\
1.00 & 0.95
\end{tabular}

\section{Spending on special products}

11. Spending on special products by business and government

44,821

51,242

60,834

67,418

75,531

87,222

101,146

\section{Agqregate price indexes for special products}

12. Business and government investment

13. percent change

1.00

$$
0.90
$$$$
-10.0
$$

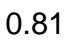

$-9.8$

0.71

$-13.2$

0.60

$-15.5$

0.51

$-14.0$

0.44

$-13.3$

\section{Construction of business and government price index}

Assume PPI falls 4 percent per year faster than actual

14. Modified PPI for communications equipment

15. Aggressive communications equipment price index

16. percent change

1.00

$$
0.97
$$

0.94

0.90

0.86

$$
\begin{aligned}
& 0.92 \\
& -7.9
\end{aligned}
$$

0.85

0.76

$-10.8$

1.00

$$
\begin{aligned}
& 0.96 \\
& -4.0
\end{aligned}
$$

0.94
-25

0.93
-1.0

1.00

0.84

$-16.1$ 
Table 17: Summary of price indexes for communications equipment

(all price indexes $=1.00$ in 1994)

Conservative

percent change

Moderate

percent change

Aggressive

percent change

BEA communications equipment percent change

BEA computers

percent change

\begin{tabular}{|c|c|c|c|c|c|c|c|}
\hline 1994 & 1995 & 1996 & 1997 & 1998 & 1999 & 2000 & AAGR $(\%)$ \\
\hline \multirow[t]{2}{*}{1.00} & 0.96 & 0.92 & 0.87 & 0.80 & 0.74 & 0.67 & \multirow[t]{2}{*}{-6.4} \\
\hline & -4.5 & -3.6 & -5.8 & -7.7 & -8.1 & -8.4 & \\
\hline \multirow[t]{2}{*}{1.00} & 0.94 & 0.88 & 0.81 & 0.73 & 0.66 & 0.60 & \multirow[t]{2}{*}{-8.3} \\
\hline & -6.4 & -5.8 & -8.1 & -10.2 & -9.7 & -9.3 & \\
\hline \multirow[t]{2}{*}{1.00} & 0.92 & 0.85 & 0.76 & 0.66 & 0.58 & 0.51 & \multirow[t]{2}{*}{-10.6} \\
\hline & -7.9 & -8.0 & -10.8 & -13.0 & -12.2 & -11.6 & \\
\hline \multirow[t]{2}{*}{1.00} & 0.96 & 0.94 & 0.93 & 0.89 & 0.86 & 0.83 & \multirow[t]{2}{*}{-3.0} \\
\hline & -4.0 & -2.5 & -1.0 & -4.1 & -3.6 & -2.8 & \\
\hline \multirow[t]{2}{*}{1.00} & 0.84 & 0.64 & 0.49 & 0.36 & 0.28 & 0.24 & \multirow[t]{2}{*}{-21.20} \\
\hline & -16.1 & -24.0 & -22.5 & -26.4 & -23.8 & -13.6 & \\
\hline
\end{tabular}


Table 18: Changes in Average Annual Growth Rates for Real Investment Using Various Price Indexes for Communications Equipment

Increase in average annual growth from 1994 to 2000

\begin{tabular}{lrrr} 
& $\begin{array}{c}\text { Communications } \\
\text { equipment }\end{array}$ & $\begin{array}{c}\text { Information } \\
\text { processing } \\
\text { equipment }\end{array}$ & $\begin{array}{c}\text { Non-residential } \\
\text { investment }\end{array}$ \\
\cline { 2 - 4 } Conservative & 4.1 & 0.9 & 0.4 \\
Moderate & 6.6 & 1.5 & 0.6 \\
Aggressive & 9.8 & 2.2 & 0.9
\end{tabular}

